\title{
Stefnumiðuð stjórnun: Fimm greiningarlíkön
}

\section{Runólfur Smári Steinpórsson ${ }^{1}$}

\section{Ágrip}

Stjórnun gerir kröfu um að náð sé utan um mikilvægar forsendur og frumsetningar. petta á sérstaklega við um stefnumiðaða stjórnun. Til viðbótar við undirstöðuatriði stjórnunar er með stefnunni búið að marka frekar og skerpa á peim forsendum sem taka á mið af við próun viðkomandi starfsemi. Pessar forsendur gefa starfseminni grunngildi, ákveða sýn á fyrirtækið, tilgang pess og framlag til umhverfisins. Нvað pað á pátt í að gera og hvað pað verður að búa við.

Fyrirtæki er umgjörð utan um kvika starfsemi og stöðugt parf að takast á við breytingar hið ytra og hið innra. Með umgjörðinni er komið á böndum til að auðvelda meðferð og ráðstöfun peirra auðlinda sem fyrirtækið nýtir til að ná tilgangi sínum. Árangurinn veltur á samstillingu milli pess sem fyrirtækið kann og getur og hver eftirspurn er í umhverfi pess. Stefnumiðuð stjórnun snýst á hverjum tíma um að ná sem mestum árangri í rekstri fyrirtækisins á grundvelli afstöðu um hvað fyrirtækið vill vera og vill verða.

Pessi grein varpar ljósi á atriði, pætti og víddir sem skipta máli við stefnumiðaða stjórnun fyrirtækja. Eftir yfirlit yfir fagið er kynnt fjórvítt greiningarlíkan sem gefur yfirsýn yfir pau atriði sem draga parf fram í greiningu á starfsemi ef stjórna á stefnumiðað. Fyrir hverja af fjórum víddum stefnumiðaðrar stjórnunar er síðan gerð grein fyrir sérstöku greiningarlíkani.

Útgangspunkturinn er að stefnumiðuð stjórnun sé viðvarandi viðfangsefni hjá peim fyrirtækjum sem ná árangri. Ætlunarverkið er að fræða lesandann um pau fjölmörgu atriði sem máli skipta við stefnumiðaða stjórnun.

\begin{abstract}
The main aim of this article is to present a framework that can be of use in understanding strategic management and doing strategy analysis. In the article a four dimensional view of strategic management is described and further developed into a framework to be used in strategy analysis. The four dimensional framework is then broken up and further developed into frameworks for each of the dimensions. The frameworks highlight aspects and issues that are important for an understanding how organizations are managed strategically, regardless of whether the focus is on activities in the past or present, or on preparing the organization for activities in the future.
\end{abstract}

JEL- flokkun: M1; L1; L2; L3

Lykilhugtök: Stefna; stefnumiðuð stjórnun; greiningarlíkön

${ }^{1}$ Höfundur er dósent í viðskipta- og hagfræðideild Háskóla Íslands. 


\section{Inngangur}

Stefnumiðuð stjórnun er í pessari grein í brennidepli. Stefnumiðuð stjórnun er samsett heiti á fagi sem flestir pekkja sem stefnumótun, stefnumarkandi áætlunargerð eða jafnvel markvissa stjórnun ${ }^{2}$. Stefnumiðuð stjórnun hefur að geyma fjölmargar kenningar og aðferðir til markvissrar stjórnunar á fyrirtækjum, opinberum stofnunum, félögum eða öðrum skipulagsheildum. Pessar kenningar hafa verið að próast alla síðastliðna öld, en pó einkum undanfarin fjörutíu ár. Fræðasviðið á sér pó uppruna og fyrirmyndir sem eru miklu eldri. Petta svið hefur átt síauknum vinsældum að fagna og próun pess síðustu áratugina hefur einkennst af mikilli grósku. Framlag til kenninga um stefnumótun og framkvæmd stefnu hefur komið úr mörgum ólíkum áttum og ritverkin hafa byggst á mismunandi sjónarhornum³ ${ }^{3}$.

Tilgangurinn hér er að varpa nokkru ljósi á stefnumiðaða stjórnun og setja fram hagnýta útfærslu á fræðunum fyrir íslensk fyrirtæki og stofnanir. Fyrst er vikið að pörfinni fyrir stefnumiðaða stjórnun, pá er stefnumiðaðri stjórnun lýst og að lokum er fjallað um víddir stefnumiðaðrar stjórnunar. Dregnar eru fram myndir, greiningarlíkön, sem ætlað er að auðvelda stjórnendum og öðrum áhugamönnum um stefnumiðaða stjórnun að ná utan um viðkomandi starfsemi og til að bæta stjórnun hennar.

Pessi grein byggist á rannsókn höfundar frá árunum 1991-1994 og birt var í doktorsritgerð hans 19954. Hér er pó ekki um pýðingu að ræða heldur nánari útfærslu sem grundvallast á flokkun og líkönum sem sett voru fram í ritgerðinni ${ }^{5}$.

\section{Pörfin fyrir stefnumiðaða stjórnun}

Stefnumiðuð stjórnun snýst um að ná sem bestum árangri í rekstri tiltekinnar skipulagsheildar. Árangurinn grundvallast á afstöðu um pað sem fyrirtækið vill vera og vill verða til lengri tíma litið. Í pessu felst m.a. stjórnun sem miðar að pví að skapa, treysta og próa stöðu og pýðingu fyrirtækisins ${ }^{5}$ í umhverfi sínu. Petta á bæði við ytra

\footnotetext{
2 Stefnumiðuð stjórnun er hér sett fram sem pýðing á „strategic management”. Stefnumiðuð stjórnun sem sjálfstætt fræðasvið á sér hálfrar aldar sögu en rannsóknarefnið hefur verið pekkt í árpúsundir. Upplýsandi texti um próun stefnumiðaðrar stjórnunar er bók Schendels \& Hofers 1979. ${ }^{3}$ Víða má sjá viðleitni til að gefa yfirlit yfir fagið, t.d. Mintzberg o.fl. 1998 og Jenkins \& Ambrosini 2002

${ }^{4}$ Runólfur Smári Steinpórsson. Strategisk ledelse af mellemsektororganisationer. 1995. 5 Höfundur hefur í tvígang, 1994 og 1999, gert grein fyrir hluta af peim hugmyndum sem hér eru kynntar og eðlilegt er að skoða pessa grein sem framhald á peim verkum. Höfundur vill koma á framfæri pakklæti til Ólafs Jónssonar fyrir gagnlegar athugasemdir. Einnig fær ritstjóri pakkir fyrir góðar ábendingar og ritrýnendur sömuleiðis.

${ }^{5}$ Pær stjórnunarhugmyndir sem hér er fjallað um eiga við um hvers konar skipulagsheildir. Helstu flokkar skipulagsheilda eru fyrirtæki, félög og stofnanir, sbr. umfjöllun höfundar 1995a. Til einföldunar verður eftirleiðis í greininni eingöngu vísað til fyrirtækis. Рað ber pó ekki að skilja pannig að hægt sé að leggja pessar gerðir skipulagsheilda að jöfnu. Margt er ólíkt í starfsemi og
} 
og innra samhengi starfseminnar. Takmarkið er að tryggja árangur fyrirtækisins í víðustu merkingu, p.m.t. góða arðsemi og góða ímynd, bæði til skemmri og lengri tíma litið. Alla jafna pegar vísað er til umhverfisins pá er átt við ytra umhverfi fyrirtækisins, sem er að verða bæði fjölbreyttara og flóknara. Af pví leiðir að stjórnendum er sífellt stærri vandi á höndum við pað verkefni að tryggja að fyrirtækið starfi í sátt við umhverfi sitt. Sé ekki fylgst náið með og unnið stefnumiðað getur pað hent fyrirtækið, eins og skip, að pað reki af leið og lendi í hreinum ógöngum. Раð getur strandað eða jafnvel sokkið.

Fyrirtækjum stendur ógn af margs konar tilvistarvá. Аð sama skapi bjóðast fyrirtækjum mörg tækifæri. Stefnumiðuð framvinda athafna veltur á pví að fyrirtækið standist samkeppni á markaðinum. Fyrirtæki starfa jafnan á samkeppnismarkaði. Pað er lykilatriði í stefnumiðari stjórnun að draga fram og hlúa að pví sem eflir og styður við samkeppnishæfni fyrirtækisins. Samkeppnishæfnin á sér tvenns konar rætur, annars vegar í markaðsstöðu fyrirtækisins og viðskiptasamböndum og hins vegar í sérstakri færni og getu fyrirtækisins til að veita pá pjónustu sem eftirspurn er eftir. Pað er grundvallaratriði að stjórnendur átti sig á peim atriðum og páttum sem fyrirtækið verður að ráða við til að standast samkeppnina og ná árangri. Slík atriði eða pættir nefnast lykilárangurspættir'

Pörf fyrirtækja fyrir stefnumiðaða stjórnun er margvísleg og fer eftir stöðu hvers peirra á viðkomandi markaði, skipulagi peirra og peim tengslum og verðmætum sem máli skipta. Vandinn er meiri eftir pví sem ástand fyrirtækisins er lakara og staða pess í rekstrarumhverfinu er verri í samanburði við önnur fyrirtæki. Til að meta ástandið og stöðuna er nauðsynlegt að huga að ólíkum rótum vandans,

t.d.: a) minnkandi eftirspurn eftir pjónustu fyrirtækisins, b) versnandi ímynd fyrirtækisins, c) skipulagsvanda og skorti á liðsheild og d) versnandi afkomu7. Pað sést á pessari flokkun að vandamálin sem hugtök og aðferðafræði stefnumiðaðrar stjórnunar geta hjálpað til við að leysa eru sjaldnast einangruð eða gagnkvæmt útilokandi. Flokkun sem pessi getur pví reynst gagnleg til að ná áttum í stefnumótunarvinnunni og betri miðun getur leitt til markvissari stjórnunar pess fyrirtækis sem leitast við að vinna stefnumiðað.

Fræðin um stefnumiðaða stjórnun hafa verið að próast til að greina betur og bæta pær leiðir sem fyrirtæki geta farið til að leysa úr vandamálum sínum. Fræðaflóran leysir einnig úr mismunandi pörfum og óskum stjórnenda fyrir leiðbeiningar um árangursríka stjórnun. Framan af var aðaláherslan í stefnumótunarfræðunum á próun hugtaka og greiningarverkfæra til mótunar á stefnu. Fræðimennirnir skeyttu minna um framkvæmd stefnunnar. Dæmi um petta er áherslan á stefnumarkandi áætlanagerð ${ }^{8}$. Vinna við stefnumarkandi áætlanagerð fer jafnan pannig fram að fyrst eru meginmarkmið fyrirtækisins dregin fram, síðan er unnin hlutlæg og rökræn greining á stöðu fyrirtækisins, styrkleikum pess og veikleikum sem og peim

umhverfi fyrirtækja annars vegar og opinberra stofnana hins vegar, en sömu aðferðir koma að gagni við stjórnun peirra.

${ }^{6}$ Sjá Ohmae 1982.

7 Jörgensen 1977.

8 Í bókinni Strategy Safari eftir Mintzberg o.fl. 1998 er gerð ítarleg grein fyrir pessari nálgun í stefnumiðaðri stjórnun. Par er fjallað um petta sem „,hönnunarskólann“ og ,,áætlunarskólann“. Í bókinni er alls fjallað um tíu „skóla“ stefnumótunar. 
tækifærum og hættum sem pað býr við. Á grundvelli pessara upplýsinga eru dregnir fram peir kostir sem fyrirtækið hefur við val á stefnu. Pvínæst er stefna valin og gert ráð fyrir að hún verði framkvæmd.

Pessi algenga nálgun að stefnumótunarvinnu felur í sér pann skilning að sjálf stefnumótunin sé aðalatriðið til að tryggja árangur fyrirtækja. Litið er á framkvæmd stefnunnar sem nokkuð sjálfgefna. Reynslan hefur sýnt að pessi skilningur er ófullnægjandi. Hvort tveggja er að vandamálin sem fyrirtæki eru að fást við og lausnirnar sem duga eru mun flóknari en algengustu kenningar um stefnumarkandi áætlanagerð gera ráð fyrir. Val á stefnu sem miðar að tiltekinni stöðu fyrirtækis í umhverfinu og hæfi pess til tekjuöflunar tryggir ekki árangurinn. Til að árangur náist parf jafnframt að taka inn í myndina athafnir og venjur fyrirtækisins í víðu samhengi, skipulag pess og færni starfsmanna. Í stefnumiðaðri stjórnun er einnig lykilatriði að taka mið af óskum og pörfum viðskiptavina, afstöðu eigenda og væntingum helstu hagsmunaaðila.

Rannsóknir hafa sýnt að árangurinn af stefnumarkandi áætlanagerð hefur ekki verið í samræmi við væntingar ${ }^{9}$. Ein skýring á pví er sú að áætlanagerðin hefur stundum verið falin ákveðinni deild eða sérfræðingum sem hafa ekki ávallt gætt pess að vera í nægum tengslum við aðrar deildir eða starfsmenn viðkomandi fyrirtækis eða stofnunar. Búi fyrirtæki t.d. við mjög sérhæft starfaskipulag er meiri hætta á að peir sem vinna að stefnumótun annars vegar og peir sem framkvæma eiga stefnuna hins vegar tali ekki saman og jafnvel skilji ekki hver annan. Aðrar skýringar á pví að pessi nálgun við stefnumótun og framkvæmd stefnu hefur ekki skilað peim ávinningi sem vænst hefur verið eru m.a. mistök við afmörkun og skilgreiningu á starfsgrundvelli fyrirtækisins, mistök við útfærslu starfseininga, einhliða áhersla á töluleg markmið, ójafnvægi í sampættingu innri og ytri pátta, skortur á boðskiptum auk hreinna mistaka stjórnenda. Einnig eru dæmi um að stefnumörkun hafi verið of almennt orðuð og algengt er að pað skorti á samræmi milli atriða eins og upplýsingakerfa, áætlanagerðar, fyrirkomulags við eftirlit og aðferða við hvatningu' ${ }^{10}$.

\section{Lýsing á stefnumiðaðri stjórnun}

Stefnumiðuð stjórnun er nú afmarkað fag innan stjórnunar. Рað sem einkennir hana öðru fremur er hversu pverfagleg hún er. Pví eru peir sem rannsaka stefnumiðaða stjórnun oft ósammála um áherslur og skilgreiningar ${ }^{11}$. Vegna pessa eru átakalínur innan fræðanna. Skilgreiningar, kenningar og líkön fræðimannanna draga dám af ólíkum forsendum og mismunandi sjónarhornum. Fræðiheimur stefnumiðaðrar stjórnunar er pví langt frá pví að vera einsleitur. Petta verða stjórnendur að hafa í huga pegar peir sækja leiðbeiningar og stuðning í fræðin, hvort heldur á eigin spýtur eða með hjálp ráðgjafa. Stjórnendur verða einnig að átta sig á að ráðgjafar eru jafnan boðberar og talsmenn tiltekinna fræða, aðferða og kenninga, jafnvel óháð pví hvers

\footnotetext{
${ }^{9}$ Sjá umfjöllun í bók Mintzbergs frá 1994.

${ }^{10}$ Sjá m.a. Judson 1996.

${ }^{11}$ Sjá De Wit og Meyer 1994.
} 
konar fyrirtæki peir eiga að pjóna. Um fræðiheiminn fara tískustraumar og nýjungar birtast nánast vor og haust. Pess vegna er mikilvægt að stjórnendur geti gert greinarmun á fræðilegri tískubylgju, sem oftast hefur skammvinn áhrif, og klassískri pekkingu sem bætir hag til lengri tíma litið. Í pví skyni verða stjórnendur ávallt að kanna og gera sér grein fyrir peim forsendum, rannsóknum og reynslu sem býr að baki tilboði um pjónustu á einhverju fræðasviði, t.d. á sviði stefnumiðaðrar stjórnunar.

Algengast er að kenningar um stefnumiðaða stjórnun séu settar fram í formi aðferða og verkfæra sem ætlað er að leysa vel afmarkað vandamál. Slíkar stjórnvísindalegar kenningar og líkön draga fram í fyrirtækinu pá pætti sem eru af tæknilegum og efnahagslegum toga, en líta fram hjá öðrum og oft mikilvægari páttum. Aðrar kenningar draga fram fyrirtækið sem bandalag hagsmunaaðila par sem innsýn í valdatafl og baráttu milli aðila utan og innan fyrirtækisins er talin meginforsenda árangurs við stefnumótun og ákvarðanatöku. Út frá pessu sjónarhorni nægir ekki að fyrirtæki einbeiti sér að pví að nýta sem best hagrænar auðlindir sínar heldur er litið svo á að sátt á milli ráđandi hagsmunaaðila skipti mestu máli sem og víðtæk viðurkenning á starfi fyrirtækisins í samfélaginu. Priðja sjónarhornið sem hér verður nefnt byggist á pví að skoða starfsemi fyrirtækja í enn víðtækara samhengi. Til viðbótar við tækni, hag, völd og stjórnmál er menning, túlkun og skilningur á starfsemi fyrirtækisins, tilgangi og samhengi pess aðalatriðið ${ }^{12}$. Í pessu ljósi sést að stefnumiðuð stjórnun snertir próun á sjálfsmynd fyrirtækis og áhersla er á aðgerðir sem stuðla að skilningsmótun og samstillingu meðal lykilhagsmunaaðila ${ }^{13}$. Stefnumiðuð stjórnun snýst um að efla sameiginlegan skilning til að ná lengra og gera betur.

\section{Stefnumiðuð stjórnun í sögulegu ljósi}

Samstaða varð um pað meðal fræðimanna að stefnumiðuð stjórnun fyrirtækja hlyti viðurkenningu sem sjálfstætt fag upp úr 1960. Um pað leyti birtast fyrstu heilsteyptu kenningarnar ${ }^{14}$ um efnið. Fram að pví er vart hægt að segja að stefnumótun fyrirtækja hafi verið til sem kerfisbundin aðferðafræði. Fagið á sér lengri próunarsögu ${ }^{15} \mathrm{sem}^{\mathrm{s}}$ talið er að hefjist upp úr 1850 með einstaklingsbundnum áætlunum. Árið 1910 hefst svo fjárhagsleg áætlanagerð með áherslu á starfaskiptingu. Áætlanir voru gjarnan til eins árs.

Frumskeið eiginlegra stefnumótunarkenninga er talið hefjast í kjölfar síðari heimsstyrjaldarinnar. Mest ber á áætlanagerð í fyrstu. Áætlanagerðin er bundin við deildir með tveggja til priggja ára tímaramma og síðar gerð langtímaáætlana fyrir fyrirtækið í heild til ýmist fjögurra eða fimm ára. Einkennandi fyrir petta skeið er að stjórnendur skoða reksturinn innan frá, sem nokkurs konar lokað kerfi, par sem reynt er að treysta styrkleika fyrirtækisins og draga úr veikleikum pess. Pær kenningar sem

\footnotetext{
12 Um petta fjalla m.a. Berg og Jonsson 1991.

13 Sjá m.a. Weick, 1995.

14 Chandler, 1962; Ansoff, 1965; Andrews, 1987.

15 Yfirlit er að finna hjá Judson, 1996.
} 
komu fram á pessu skeiði hafa verið nefndar línulegar í ljósi pess að umhverfið var talið stöðugt og fyrirsjáanlegt ${ }^{16}$.

Annað skeið í próun fagsins er svo tímasett um 1970. Yfirskrift pessa skeiðs er stefnumarkandi áætlanagerð. Kenningarnar snúast einkum um markaðssvörun og hæfi fyrirtækisins til að standast samkeppni. Áhersla er lögð á stöðugreiningu og samkeppnisgreiningu. Sú breyting er orðin á að stjórnendur líta á reksturinn utan frá. Sérstök áhersla er lögð á að fyrirtækið sé markaðssinnað og að pað nýti sér markaðsrannsóknir. Umhverfið er síbreytilegt og takmarkið er að marka skýra stefnu. Síðan er gengið út frá pví að auðlindum fyrirtækisins sé ráðstafað til samræmis við stefnuna til að árangur náist.

Priðja skeiðið í próun stefnumiðaðrar stjórnunar hófst síðan 1985. Meginmálið snerist pá um að láta kenningarnar taka mið af pví að samræma pyrfti í sífellu alla pætti í starfsemi fyrirtækja með tilliti til gefins takmarks. Litið er á fyrirtækið sem flókna efnahagslega, félagslega og menningarlega einingu. Horft er á forsendur fyrirtækisins til verðmætasköpunar í víðara ljósi en áður. Áhersla er á sveigjanleika í skipulagi og sköpunargáfu starfsfólks. Umboð starfsmanna til athafna verður víðtækara og ábyrgð peirra á starfspáttum meiri en áđur. Menning fyrirtækisins og gildismat fær grundvallarpýðingu.

Rök hníga að pví að nú megi marka fjórða skeiðið sem tekur flugið upp úr 199017. Megináherslan pá er á auðlindir fyrirtækisins og mikilvægi samlegðaráhrifa milli eininga í rekstri. Ný tækni kemur fram, svo sem internetið og veraldarvefurinn. Kastljósinu er beint að pekkingarverðmætum og peim innviðum í fyrirtækinu sem ekki skila arði. Flett er ofan af duldum eignum og fyrirtækjum er skipt upp í kjarnaeiningar. Leitað er nýrra leiða í verðmætasköpun og við mælingar á árangri. Áhersla er lögð á endurmótun, endurhögun ferla og endurskipulagningu samhliða fjármálalegri greiningu. Einnig er mikið lagt upp úr raunhagnaði. Mikilvægt er að sem flestir starfsmenn séu pátttakendur í stefnumiðaðri stjórnun fyrirtækisins, sem miðar að pví að efla sérstaka færni, samkeppnis- og samstarfshæfni fyrirtækisins, bæði inn á við og út á við. Áhersla er lögð á að hagnýting tækni og öll kerfisgerð sé jafnframt útfærð í samræmi við stefnu fyrirtækisins og markvissa próun pess. Litið er á umhverfið í víðu ljósi og sérstaka athygli fá samstarfslausnir í verðmætasköpun og netáhrif hvers konar. Helstu drifkraftar breytinganna liggja í alpjóðavæðingu og tæknipróun.

Pessi próun fagsins sem hér hefur verið rakin pýðir að í stefnumiðaðri stjórnun er mikilvægt að sjá samofna alla pætti sem hafa áhrif á próun fyrirtækis. Petta á við um grunngildin, stefnumótunina, taktíska úrvinnslu og hina daglegu stjórnun aðgerða. Áhersla parf að vera á sambandið við viðskiptavininn og hlúa parf að víxlverkandi tengslum við alla pá sem koma að verðmætasköpun fyrirtækisins. Sérstaklega parf að huga að lærdómi og sköpun pekkingar, svo og miðlun og hagnýtingu pekkingarverðmæta, ekki síst með hjálp öflugra upplýsingakerfa. Hvað stefnumiðaða stjórnun varðar pá kallar petta á virka og stöðuga stefnumiðaða hugsun og virka samræðu innan fyrirtækisins um starf pess, próun og möguleika til framtíðar.

\footnotetext{
${ }^{16}$ Sjá Chaffee, 1985: a) „linear model“ , b) „,adaptive model“ og c) „,interpretive model“.

${ }^{17}$ Grant, 2002.
} 


\section{Stefnumiðuð stjórnun - fjórar víddir til greiningar}

Í virkri samræðu um próun fyrirtækis eða stofnunar skipta kenningar og leiðbeinandi líkön um stefnumiðaða stjórnun sköpum. Eitt peirra sem notast má við er eftirfarandi greiningarlíkan af víddum stefnumiðaðrar stjórnunar. Pað er rétt að taka fram að petta líkan var próað sem rannsóknarverkfæri til að draga fram pær forsendur og pau séreinkenni sem koma fram og setja mark sitt á stefnumiðaða stjórnun tiltekinnar skipulagsheildar ${ }^{18}$. Líkanið er afmarkað við hugtök og hugmyndir um stefnumiðaða stjórnun. Pað er pví sem slíkt opið og óhlutbundið. Líkanið er hugsað sem rammi sem notast má við til pess að öðlast innsýn og skilning á peim atriðum sem snerta stefnumiðaða stjórnun almennt. Pessi atriði snerta stefnumiðaða stjórnun í öllum gerðum af skipulagsheildum, án tillits til pess hvort pær tilheyra einkageiranum, opinbera geiranum eða priðja geiranum ${ }^{20}$.

Greiningarlíkanið gerir auðveldara að draga fram pau atriði sem mynda samofið munstur athafna og próunar, bæði innan og utan fyrirtækja og stofnana. Munstrið kemur fram pegar stefnumiðuð stjórnun í tiltekinni skipulagsheild er skoðuð, með öðrum orðum pegar horft er á starfsemina í pví samhengi sem hún er. Athafna- og próunarmunstur í ólíkum gerðum af skipulagsheildum virðast vera mismunandi um margt. Pennan mismun má draga fram sem rök fyrir pví að forsendur og lögmál stefnumiðaðrar stjórnunar séu ekki pær sömu fyrir allar gerðir af skipulagsheildum. Mikilvægt er að skoða petta frekar, sérstaklega í ljósi pess að deildar meiningar eru um pað hversu mikill munur er t.d. á milli stjórnunar fyrirtækja og opinberra stofnana.

Víddir stefnumiðaðrar stjórnunar eru hér taldar vera fjórar, sbr. mynd 1. Með einföldun má segja að með víddunum sé verið að draga fram atriði sem birtast ef eftirfarandi spurningum er svarað: a) Tilvist: hvers vegna er skipulagsheildin til staðar; b) Innihald: um hvað snýst starfsemi hennar; c) Ferli: hvernig fer starfsemin fram; d) Samhengi: úr hverju, hvar, af hverjum og fyrir hverja er starfsemin framkvæmd.

Með spurningunni í lið a) er bent á pá vídd sem skýrir tilvist skipulagsheildarinnar. Pessi vídd er ein sú mikilvægasta við stefnumiðaða stjórnun, pví undir hana falla atriði eins og sampykktir, lög og hvers kyns afstaða sem lýsir tilgangi starfseminnar, mótar hlutverk hennar og framtíðarsýn í grófum dráttum. Pessi atriði eru skilgreind hér sem tilvistargrundvöllur skipulagsheildarinnar.

Með spurningunni í lið b) er bent á pá vídd sem er lýsandi fyrir innihaldið eða pá starfsemi sem skipulagsheildin snýst um. Petta eru atriði eins og athafna- eða viðskiptasvið, vinnslusvið og samkeppnisáherslur. Pessi atriði eru skilgreind hér sem starfsgrundvöllur skipulagsheildarinnar.

\footnotetext{
${ }^{18}$ Petta líkan var sett fram í doktorsritgerð höfundar. Höfundur studdist við prískiptingu frá Pettigrew, sbr. Pettigrew \& Whipp, 1991: „,content, process, context“. Hann bætti við fjórðu víddinni og tilgreind uppsetning og útfærsla er hans, sbr. Runólfur Smári Steinpórsson, 1995. 20 priðji geirinn stendur fyrir priðja aðalmengið af skipulagsheildum. Til priðja geirans teljast félög af ýmsu tagi, t.d. ípróttafélög, trúfélög, fagfélög og stjórnmálaflokkar. Sjá nánari umfjöllun í ritgerð höfundar frá 1995.
} 


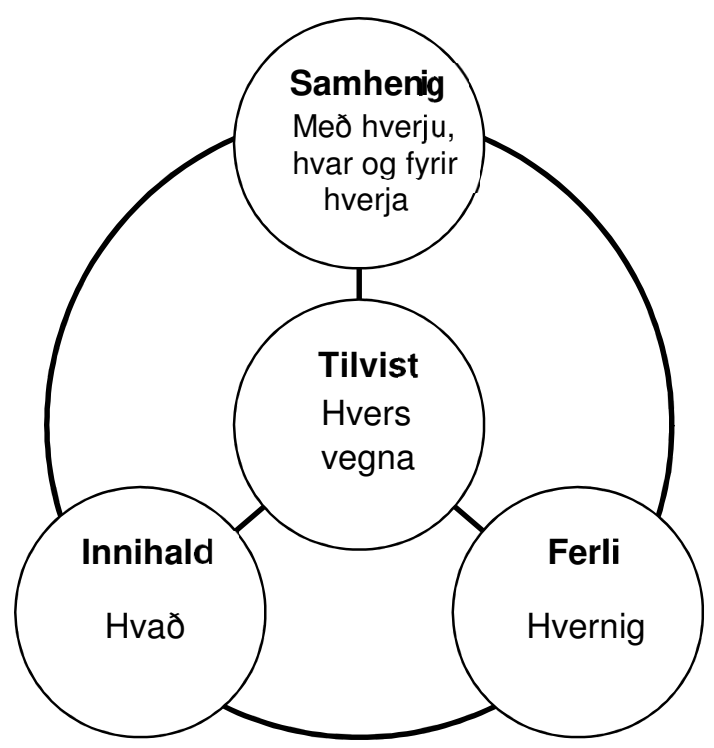

Mynd 1. Fjórar víddir stefnumiðaðrar stjórnunar

Með spurningunni í lið c) er bent á pá vídd sem er lýsandi fyrir ferli starfseminnar sem og pær aðferðir og venjur sem mótast hafa í skipulagsheildinni til að ná árangri. Petta eru atriði eins og fyrirkomulag funda, vinnulag, kerfisnotkun og óformlegir og formlegir starfshættir. Pessi atriði eru skilgreind hér sem hinir mótandi og einkennandi starfshættir skipulagsheildarinnar.

Með spurningunni í lið d) er bent á pá vídd sem er lýsandi fyrir samhengi starfseminnar. Pá er átt við bæði pað ytra og innra samhengi sem skiptir máli fyrir starfsemina. Petta eru atriði eins og hagkerfi, stjórnmálaumhverfi, félagslegt umhverfi, athafnasvæði, viðskiptavinir, aðrir hagsmunaaðilar, eigendur, auðlindir, tækni, menning, starfsmenn og skipulag. Pessi atriði eru skilgreind hér sem hið stefnumiðaða samhengi skipulagsheildarinnar.

Í peirri nálgun við stefnumiðaða stjórnun skipulagsheilda ${ }^{19}$ sem hér er beitt er lögð áhersla á að allar víddirnar komi fram í skilgreiningu á stefnumiðaðri stjórnun. Í ljósi víddanna má líta á stefnumiðaða stjórnun sem pað árangursríka, rásfasta og síendurtekna munstur athafna-ákvarðana og ákvarðana-athafna tiltekinnar skipulagsheildar, par sem saman fara forsendur, skilyrði og aðgerðir sem skapa, móta og endurmóta tilgang, hlutverk, starfssvið, starfsaðferðir, stefnu og samhengi skipulagsheildarinnar á tilteknu tímabili.

Til að átta sig betur á hvað skiptir máli við stefnumiðaða stjórnun er mikilvægt að líta nánar á atriðin í pessari skilgreiningu. аð verður best gert með pví að skoða víddirnar nánar.

\footnotetext{
${ }^{19}$ Lesanda er bent á að í pessum kafla hefur höfundur kosið að víkja frá peirri reglu sem hann annars hefur í greininni, að fjalla fyrst og fremst um stefnumiðaða stjórnun fyrirtækja. Greiningarlíkanið er hugsað óhlutbundið og pví er ætlað að nýtast jafn vel við greiningu á stefnumiðaðri stjórnun hjá hinu opinbera, hjá félagasamtökum sem og milliaðilum. Skal bent á grein eftir Steinpórsson og Söderholm, 2002, til vitnis um pað.
} 


\subsection{Tilvistarvíddin}

Öll fyrirtæki hafa ákveðinn tilgang eða ákveðnu hlutverki að gegna. Fyrirtæki marka sér jafnframt framtíðarsýn, p.e. ákveðna afstöðu um hvaða árangri skuli náð í bráð og lengd og hvaða ímynd fyrirtækið vill öðlast.

Hér er bent á að pað geti verið gagnlegt að skoða pennan grundvöll fyrir stefnumörkun og markvisst próunarstarf fyrirtækja í víðara ljósi. Pannig varð hugmyndin um tilvistargrundvöll til ${ }^{20}$. Tilvistargrundvöllurinn stendur í raun sem bakgrunnur viðkomandi fyrirtækis og pað víðtæka samkomulag sem umbjóðendur fyrirtækisins hafa í áranna rás komið sér saman um að skuli móta starfsemi pess.

Tilvistargrundvöllurinn gefur til kynna hvaða hugmyndafræði og hugmyndir liggja að baki stofnun og rekstri fyrirtækisins. Jafnframt gefur hann vísbendingar um hinar efnahagslegu forsendur fyrir tilvist pess. Pað er ekki alltaf augljóst hvort skiptir meira máli, hugmyndafræðin eða hinar efnahagslegu forsendur. Pó má reikna með að fyrirtæki sem starfa á markaði hafi í ríkara mæli verið stofnuð á efnahagslegum forsendum heldur en t.d. menningarstofnanir sem stofnað er til með lögum frá Alpingi. Stofnanir og stjórnsýsla hins opinbera taka einnig mið af öðrum forsendum en peim sem gilda t.d. um starfsemi samtaka. Samtök flokkast ekki undir einkageirann eða opinbera geirann. Pau flokkast undir priðja geirann ${ }^{21}$.

Pessu tengt er sú skoðun að pað skipti ávallt máli við stjórnun fyrirtækis hvað pað var sem réði stofnun pess. Petta má m.a. sjá í peim bókum sem til eru um fyrirtækjamenningu. Par er gert mikið úr uppruna og táknrænni pýðingu sagna og sögulegra staðreynda. Jafnframt er einatt litið á stofnandann sem hetju og fyrirmynd annarra starfsmanna. Hin sögulega skýring skiptir máli og parfnast íhugunar pegar unnið er að stefnumörkun og markvissri stjórnun í samræmi við pá stefnu sem dregin er fram. Tilvistargrundvöllurinn dregur í rauninni saman pá pætti sem mikilvægir eru í menningu fyrirtækis. Hugtakið hefur pví mikla pýðingu fyrir viðhald og viðgang sjálfsmyndar fyrirtækisins og starfsmanna pess.

Einnig kann að vera mikilvægt við stefnumiðaða stjórnun fyrirtækja að átta sig á hvaða fyrirmynd kann að vera að baki fyrirtækinu. Algengt er að stofnanir og fyrirtæki verði til að erlendri fyrirmynd. Fyrirmyndin getur hvort heldur sem er verið hugmyndafræðilegs eðlis eða rekstrarlegs eðlis.

Af framansögðu er ljóst að tilvistargrundvöllurinn er ekki eingöngu samheiti fyrir hlutverk og framtíðarsýn skipulagsheildar. Hugtakið er víðtækara og pví má skipta upp í sex pætti. Peir eru a) uppruni, b) fyrirmynd, c) hlutverk, d) meginstefna, e) stjórnunarstefna og f) framtíðarsýn:

\footnotetext{
20 Í dönskum heimildum er að finna sama hugtak eða sambærilegt. Jørgensen, 1977, notast við „,idégrundlag“ og Johnsen, 1993, notar „eksistensgrundlag“. Greinarhöfundur hafði pessi hugtök til hliðsjónar í vinnslu doktorsritgerðar en vék frá peim í eigin útfærslu.

${ }^{21}$ Ítarlega umræðu um pessa flokkun má sjá í doktorsritgerð höfundar, 1995.
} 


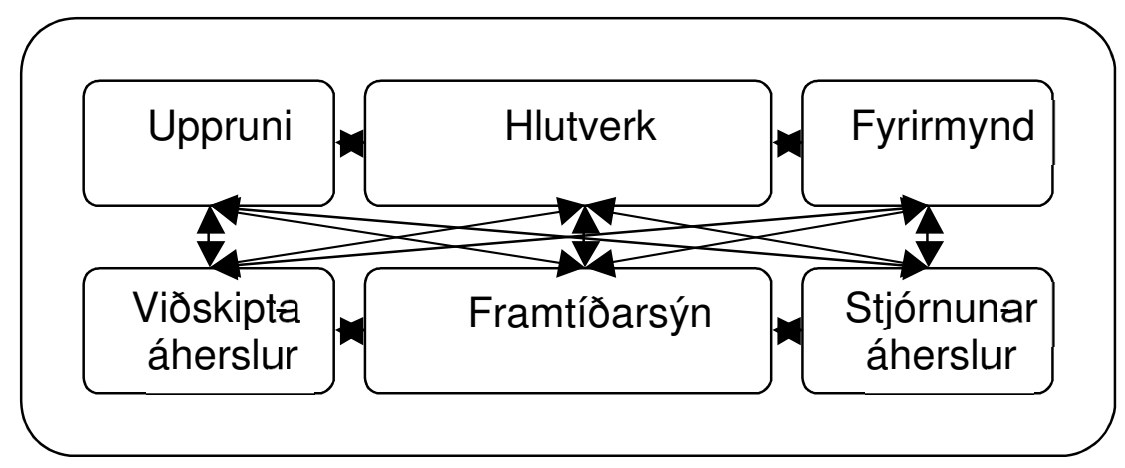

Mynd 2. Tilvistargrundvöllur

Uppruni: Eins og bent er á hér að ofan geta uppruni og saga fyrirtækisins skipt sköpum í starfi pess. Við stefnumiðaða stjórnun er pess vegna mikilvægt að athuga nánar stofnun fyrirtækisins og hvaða áherslur réðu upphaflega um starf pess. Hvað var pví ætlað að gera og hver hefur próunin verið síðan? Einnig er mikilvægt að draga fram hvaða atburðir í sögu fyrirtækisins skipta mestu máli og hvaða einstaklingar hafa sett mestan svip á starfið. Að endingu skiptir mestu máli hvaða pýðingu uppruninn og próunaráfangarnir hafa á pá starfsemi sem framundan er á vegum fyrirtækisins.

Fyrirmynd: Раð er í raun kunnara en frá purfi að segja að fyrirtæki eiga sér oftast einhverja fyrirmynd. Fyrirmyndin getur átt sér hugmyndafræðilega stoð, átt rót sína í stofnun félags eða verið af öðrum toga. Fyrirmyndin getur einnig verið ýmist bein eða óbein. Bein pegar beinlínis er hermt eftir fyrirkomulagi annars staðar frá og óbein pegar fyrirkomulag á einu sviði er fært yfir á annað svið. Samskonar starfsemi getur átt sér mismunandi fyrirmyndir. Petta sést best pegar formgerð og skipan tiltekinnar starfsemi er ólík milli landa eða landshluta. Fyrirmyndir að skipulagi fyrirtækja og stofnana geta einnig breyst í tímans rás. Pegar pað gerist er um grundvallarbreytingu að ræða sem jafnvel getur ráðið úrslitum um tilvist viðkomandi skipulagsheildar. Pví er mikilvægt að draga fram og velta fyrir sér hvað hafi ráðið útfærslu starfseminnar í áranna rás og hvaða pýðingu pær forsendur hafi enn fyrir starfsemina.

Hlutverk: Sérhvert fyrirtæki er stofnað í ákveðnum tilgangi og pví er ætlað ákveðið eða ákveðin meginverkefni. Pessi atriði eru hér sett fram undir yfirskriftinni hlutverk fyrirtækis. Með hlutverki er átt við pau meginverkefni sem fyrirtækinu er ætlað að leysa pannig að sá ávinningur sem umbjóðendur og helstu hagsmunaaðilar sækjast eftir, og sammælast um að ætlast til af starfi fyrirtækisins, verði að veruleika. Lykilatriðið hér er að átta sig á vilja umbjóðenda og helstu hagsmunaaðila. Til pess purfa stjórnendur jafnvel að beita ákveðnum aðferðum og leggja rækt við að ná sambandi og byggja upp tengsl við pá aðila sem skipta máli. Pessi vilji er að sjálfsögðu tengdur pví starfi sem fyrirtækið innir af hendi og pví umhverfi sem pað er hluti af. Hlutverk fyrirtækja er jafnan af öðrum toga en hlutverk opinberrar stofnunar, og einnig öđruvísi en t.d. ípróttafélags. Í skilgreiningu á hlutverki er í raun dregin fram sú afstaða og pær áherslur sem vísa á hvar í tilvistarrýminu fyrirtækið vill koma sér fyrir. Afstaðan myndar jafnframt útlínurnar að starfsramma fyrirtækisins og hafa að geyma megináherslurnar sem móta starfsrammann ${ }^{22}$. Niðurstaða og ákvörðun um pau

\footnotetext{
${ }^{22}$ Starfsrammi er hugtak sem höfundur notar til að lýsa stöðu, áherslum og skipulagi fyrirtækja í pví rými sem pau starfa í. Víddirnar fjórar má nota til að greina starfsrammann sem fyrirtækinu er búinn og meta hversu líklegur hann er til að skila fyrirtækinu árangri af starfseminni.
} 
meginverkefni sem sinna skal mynda jafnframt mikilvæga umgjörð fyrir útfærslu á starfsgrundvelli fyrirtækisins. Skilgreining á hlutverkinu parf að opna augu stjórnenda fyrirtækisins fyrir peim tækifærum sem bjóðast á peim sviðum sem fyrirtækið vill vinna á.

Framtíðarsýn: Framtíðarsýnin felur í sér takmarkið sem stefnt er að, pað sem fyrirtækið vill verða. Í framtíðarsýn er dregin upp mynd af peirri stöðu, skipan og ímynd sem umbjóðendur ætlast til að fyrirtækið hafi náð að byggja upp á starfsvettvangi sínum á einhverjum tilteknum tíma í framtíðinni. Með framtíðarsýn er verið að lýsa tilætluðu umfangi og pýðingu fyrirtækisins sem umbjóðendur vilja byggja upp til að gera ætlunarverk pess að veruleika. Framtíðarsýnin er leiðarljós við próun á starfsramma fyrirtækisins og er æðsta stefnumiðið. Framtíðarsýnin parf að ýta undir hvatningu í fyrirtækinu og vilja starfsmanna til lærdóms og árangursríkrar vinnu.

Viðskiptaáherslur: Viðskiptaáherslur tilheyra tilvistargrundvelli skipulagsheildar. Viðskiptaáherslurnar draga sérstaklega fram pann pátt í yfirlýsingunni um hlutverk fyrirtækis sem er leiðbeinandi um pað hvað viðkomandi fyrirtæki er ætlað að starfa við. Viðskiptaáherslurnar draga fram útlínur starfseminnar sem lýst er nánar sem starfsgrundvelli, sérstaklega gegnum hugtökin viðskiptasvið og samkeppnisáherslur ${ }^{23}$. Viðskiptaáherslurnar gefa vísbendingu um pað hvað starfsrammi fyrirtækis skuli snúast um og í hverju sérstaða fyrirtækisins skuli vera fólgin. Viðskiptaáherslurnar fela í sér leiðbeiningar um pað hvernig fyrirtæki vill nýta sér tækifæri, nánar tiltekið hvað skuli gert.

Stjórnunaráherslur: Stjórnunaráherslur eru einnig hluti af tilvistargrundvelli. Stjórnunaráherslur endurspegla hvernig fyrirtækið vill starfa. Áherslurnar gefa til kynna grundvallarhugmyndir stjórnenda og umbjóðenda um hvernig líta beri á starfsmenn, hvaða skipulagsgerð sé viðeigandi, hvaða samræmingarkerfi eigi við, hvernig hvatningu skuli háttað og hvernig meta skuli árangur. Stjórnunaráherslur purfa að stuðla að helgun starfsmanna og hollustu peirra við fyrirtækið og pær eru mikilvægur útgangspunktur fyrir próun á starfsaðferðum fyrirtækisins.

Með tilvistargrundvelli er t.d. átt við pað samhengi og pað samkomulag sem ráðandi hagsmunaaðilar hafa komið sér saman um að skuli mynda undirstöðu fyrir fyrirtæki. Petta samkomulag er af hugmyndafræðilegum toga. Í pví koma fram grundvallarviðhorf, vilji og óskir umbjóðenda (t.d. eigenda, stjórnenda og helstu hagsmunaaðila) um tilgang, hlutverk, framtíðarsýn, viðskiptaáherslur og stjórnunaráherslur viðkomandi fyrirtækis. Mikilvægt er að gera greinarmun á pessum grundvelli í fortíð, nútíð og framtíð. Til skerpingar má líta á hugtakið tilvistargrundvöll sem lýsandi fyrir pann grundvöll sem fyrirtæki hefur byggt á og grundvallast á. Í samkomulaginu um forsendur fyrir tilvist fyrirtækisins er einnig horft til framtíðar. Pann hluta samkomulagsins má útfæra sem tilvistarheit.

Hagsmunir peirra aðila sem að fyrirtækinu standa eru mismunandi og pví er ljóst að tekist er á um ýmsar og oft andstæðar áherslur. Vegna pessa er tilvistargrundvöllurinn í stöðugri próun og pau atriði sem koma inn í mótunarferlið, t.d. uppruni, fyrirmyndir og stjórnunaráherslur, setja mark sitt á pá menningu, brag og

${ }^{23}$ Pessi hugtök eru útskýrð í umfjölluninni um innihaldsvíddina, hér að neðan. 
sjálfsmynd sem fyrirtæki vinnur að og finnur fyrir. Tilvistarheitið er síðan pað virka samkomulag sem hverju sinni teiknar pann starfsramma sem er virkur og hefur mótandi áhrif á próun og stöðu fyrirtækis eða stofnunar í samfélaginu. Tilvistarheitið afmarkar starfsgrundvöll einingarinnar, er leiðarljós við próun starfshátta og aflvaki við alla skipan mála.

Aukinn skilningur stjórnenda á peim páttum sem vakin er athygli á með tilvistarvíddinni er til pess fallinn að opna augu peirra fyrir öðrum atriðum sem skipta máli við stefnumiðaða stjórnun, p.e. atriðum sem lýst er með öðrum víddum en tilvistarvíddinni.

\subsection{Innihaldsvíddin}

Innihaldsvídd stefnumiðaðrar stjórnunar dregur fram við hvað fyrirtækið starfar og hver sé varan eða pjónustan sem pað býður til sölu. Petta er að sjálfsögðu nátengt pví sem kemur fram í tilvistarvíddinni, sérstaklega í hlutverki og viðskiptaáherslum. Munurinn er að hér er tilgangurinn að ná utan um starfsemina á hlutbundnari hátt. Tilvistarvíddin hefur að geyma hugmyndafræðilegan grundvöll starfseminnar en gegnum innihaldsvíddina er reynt að ná utan um pað sem gert er í raun og gera á í náinni framtíð fyrirtækja.

Innihaldsvíddin varpar ljósi á hugtök og flokkun hugtaka sem gera mögulegt að átta sig á og greina starfsgrundvöll fyrirtækis. Starfsgrundvöllurinn samanstendur af tilætlaðri og raunverulegri pjónustu fyrirtækis og hann endurspeglar stöðu fyrirtækisins í rekstrarumhverfinu. Með framsetningu á starfsgrundvelli er ætlunin að ná utan um núverandi starfsemi fyrirtækisins, bæði í orði og verki. Mikilvægur páttur í lýsingu og greiningu á starfsgrundvelli er að horfa bæði til fortíðar og ekki síst til framtíðar, enda er takmarkið með greiningunni á starfsgrundvellinum að draga fram pær upplýsingar sem nauðsynlegar eru til að móta nýjan starfsgrundvöll.

Starfsgrundvellinum má skipta í prennt: a) viðskiptasvið og pjónustutilboð, b) vinnslusvið og samvirkni og c) samkeppnisáherslur og sérstaða²4:

${ }^{24}$ Pessi flokkun er að stofni til sótt í smiðju K.A. Jørgensens (1977) en höfundur hefur prjónað við hana. 


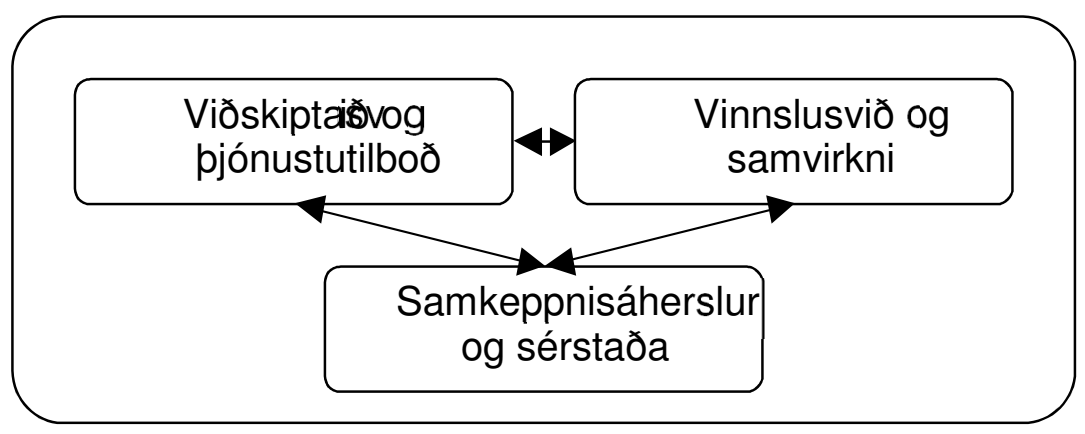

Mynd 3. Starfsgrundvöllur

Viðskiptasvið og pjónustutilboð: Nauðsynlegt er að ná vel utan um pað sem fyrirtæki hefur upp á að bjóða á peim markaði sem pað starfar. Öllum sem koma að starfinu parf að vera ljóst hvað fyrirtækið gerir, hvar, hvernig og ekki síst með hverjum pað ryður sér til rúms. Með hugtakinu viðskiptasviði er horft til tiltekins meginverkefnis í fyrirtækinu, atvinnugreinarinnar sem verkefnið fellur undir, markaðssvæðisins, viðskiptavinanna sem pað pjónar, notagildisins sem varan eða pjónustan býður upp á, parfarinnar sem pjónustan á að uppfylla, vöru- eða pjónustuflokkanna sem í boði eru, verðs og gæða, vörutækni og framleiðslutækni. Með hugtakinu pjónustutilboði er gengið lengra í sundurgreiningunni á pví sem fyrirtækið hefur í boði fyrir viðskiptavininn. Tilboð um pjónustu má t.d. flokka í kjarnaatriði, lykilatriði, stuðningsatriði, aðgengi, umgjörð, samskipti og pátttöku² ${ }^{25}$. Greining á viðskiptasviði dregur fram pað sem kalla má hina láréttu flokkun starfseminnar og snertifletina við viðskiptavinina.

Vinnslusvið og samvirkni: Starfsemi snýst ekki aðeins um vöru- og pjónustuframboð á tilteknum markaði eða mörkuðum. Hún snýst einnig um framleiðsluna, ávinning viðskiptavinarins og arðsemina. Меð öðrum orðum verðmætasköpunina. Vinnslusviðinu má lýsa með ýmsum hætti, allt eftir eðli starfseminnar. Ef um vöruframleiðslu er að ræða má grípa til hugtaks eins og virðiskeðjunnar ${ }^{26}$. Ef um pjónustu er að ræða getur reynst gagnlegra að horfa til annarra hugtaka um sama fyrirbæri, hugtaka eins og virðisnets eða virðisstofu ${ }^{27}$, virðisvönduls eða virðisstjörnu ${ }^{28}$. Pessi hugtök sýna að fyrirtæki er opið kerfi sem sækir til sín aðföng, vinnur úr peim og kemur frá sér afurðum eða pjónustu sem pað parf að hagnast á. Verðmætasköpunin verður fyrir tilstilli peirra aðila sem að verkinu koma, tækninnar sem beitt er, pekkingarinnar, færninnar og getunnar sem nýtt er. Miklu skiptir að nýta sér kosti verkaskiptingar og sérhæfingar eftir pví sem hagur býður, fá samstarfsaðila til liðs við fyrirtækið og að vinna með viðskiptavininum. Með vinnslusviðinu er verið að skapa aðstæður til að rýna í verðmætasköpunarferlið og draga fram hvaða páttum í ferlinu fyrirtækið er að sinna sjálft, hvaða páttum er úthýst og hvaða samvirkni er

\footnotetext{
25 Sjá Grönroos, 1990, 2000; Normann, 1984, 2001.

26 Porter, 1985.

27 Stabell og Fjellstad 1996 bjóða upp á hugtökin „,value net“ og ,value shop“.

28 Virðisvöndull er pýðing á „,value constellation“, hugtaki frá Normann \& Ramirez, 1994. Úr sama ranni hefur komið fram hugtakið virðisstjarna „,value star“, Normann, 2001.
} 
fyrirtækinu til hagsbóta. Markmiðið með rýninni er að sjá til pess að fyrirtækið sé ávallt að nýta auðlindir og samstarfsmöguleika sína sem allra best.

Samkeppnisáherslur og sérstaða: Fyrirtæki starfa oftast á samkeppnismarkaði og purfa að huga að peim atriðum sem tryggja peim samkeppnisforskot. Í samkeppni er ekki nægilegt að fyrirtæki hafi gert upp við sig hvað pað vilji bjóða viðskiptavinum sínum. Рað parf einnig að ákveða með hvaða hætti pað vill keppa, hvernig pað vill ná og halda forystu sinni. Mörg atriði styðja við meint eða raunverulegt samkeppnisforskot fyrirtækja og forskotið getur annaðhvort legið í lykilstöðu á markaði eða átt rót sína að rekja til sérstakrar færni og getu fyrirtækisins, eða hvorutveggja. Ein aðferðin til að ná utan um samkeppnisáherslurnar er að líta til atriða eins og kostnaðarhagkvæmni, séreinkenna, einkennandi starfshátta, sérstöðu á markaði, samstarfs og sérstakra markaðseinkenna. Jafnframt getur verið gagnlegt að fara í gegnum pað hvað auðlindir og geta fyrirtækisins leggja til samkeppnisforskots og sérstöðu fyrirtækisins. Рað er gert með pví að líta til atriða eins og tiltækra auðlinda, utanaðkomandi hermihættu, varanleika, arðsdeildar, staðkvæmdarhættu, sannanlegrar sérstöðu og pess sköpunarmátts sem er fólginn í mannauði fyrirtækisins og pekkingarverðmætum ${ }^{29}$. Samkeppnisáherslurnar og grundvöllurinn fyrir sérstöðu fyrirtækisins má í raun sjá í samkeppnisheiti fyrirtækisins, p.e. áheiti um pann árangur sem fyrirtækið ætlar að ná í samkeppninni.

Раð er algjört lykilatriði að ná vel utan um starfsgrundvöllinn í fyrirtæki sem ætlunin er að stjórna markvisst. Ein leið til pess er að horfa til svonefndra starfsmarkmiða ${ }^{30}$ sem setja má fram um einstaka pætti í starfsemi fyrirtækisins. Í gegnum starfsmarkmið birtast skilgreindir áfangar eða vegvísar um pað sem fyrirtækið ætlar sér að gera á peim sviðum sem falla undir starfsgrundvöllinn. Greining á starfsgrundvelli fyrirtækis eins og hann er í raun og veru gefur svo raunmynd af stöðu pess í rekstrarumhverfinu á tilteknum tíma og yfir tiltekið tímabil.

Í eðli sínu er framsetning á peim páttum og atriðum sem fylla innihaldsvíddina í stefnumiðaðri stjórnun ekki sérstaklega kvik eða tímatengd. Til að huga að peim pætti sérstaklega er rétt að beina athyglinni að ferlisvídd stefnumiðaðrar stjórnunar.

\subsection{Ferlisvíddin}

Með pessari vídd er hugsunin að varpa ljósi á pað hvernig tiltekið fyrirtæki starfar, hefur starfað og hvernig ætla má að pað muni starfa. Horft er til pess hvaða verklag, aðferðir og venjur hafa náð að festa rætur í fyrirtækinu ${ }^{31}$. Jafnframt er litið til atorkunnar, kraftsins og gangverksins í starfseminni. Á meðan innihaldsvíddin er útfærsla á viðskiptastefnu fyrirtækis er ferlisvíddin að svara til stjórnunarstefnunnar sem dregin var fram í umfjölluninni um tilvistarvíddina hér að framan.

Í stefnumiðaðri stjórnun er framvinda aðgerða í fyrirtækinu ekki tilviljun ein. Starfsemin getur jafnframt verið stefnumiðuð án pess pó að mjög formleg áætlun sé

\footnotetext{
${ }^{29}$ Sjá Richard Lynch, 2000.

30 Sjá Richard L. Daft, 2001.

31 Víða er að finna fræðilegar áherslur par sem ferli og munstur kemur við sögu, t.d. Quinn, 1980; Nelson \& Winter, 1982; Pettigrew, 1985; Mintzberg, 1987; Whipp o.fl. 1988; Johnson \& Scholes 2002.
} 
fyrirliggjandi. Með skilningi á tilvistargrundvelli og starfsgrundvelli má ná utan um og setja ramma og vörður til að gera starfsemi fyrirtækis markvissari. Pessi tvívíða nálgun, p.e. tilvistarvíddin og innihaldsvíddin, sem svo mjög skerpir sjónina á starfsramma fyrirtækisins er pó ekki fullnægjandi til pess að stefnumiðuð stjórnun verði árangursrík. Гаð er m.a. vegna pess að ekki er nægjanlega hugað að ferli athafnanna og samhengi peirra. Með pví að huga markvisst að mótandi og einkennandi starfsháttum fyrirtækisins má treysta stefnumiðaða stjórnun pess.

Með mótandi og einkennandi starfsháttum er vísað til próunar fyrirtækisins og pess munsturs athafna sem fyrirfinnst í pví, peirra aðferða sem pað leitast við að vinna eftir, peirra siða og venja sem hafa próast par og peirra sérstöku atburða sem stofnað er til í peim tilgangi að stuðla að og bæta pann árangur sem ætlunin er að verði af starfsemi fyrirtækisins.

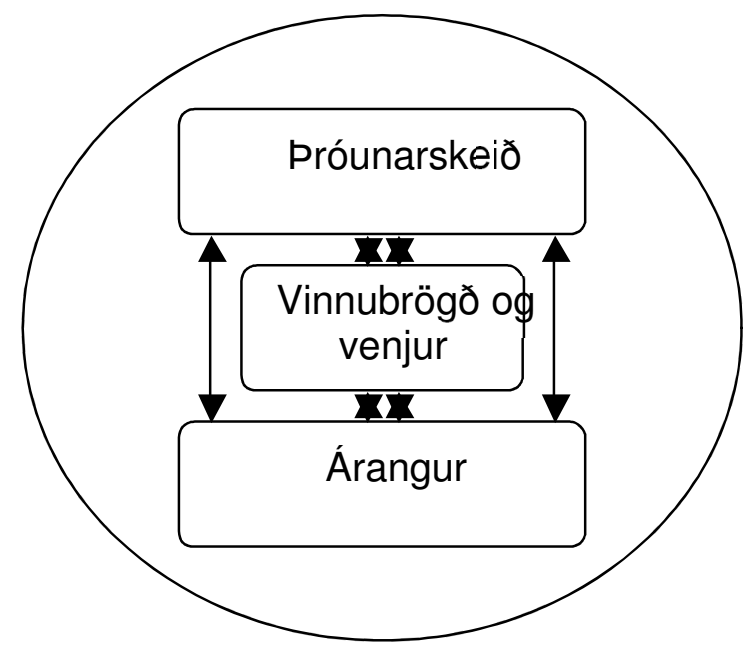

Mynd 4. Mótandi og einkennandi starfshættir

Oftast nær er pað meginmarkmið að fyrirtækið lifi til eilífðar og að pað skuli ávallt vera vel haldið. Í viðskiptaumhverfi sem er sífellt að verða flóknara og margbrotnara er ekki auðsótt að uppfylla petta meginmarkmið og pær leiðir sem fyrirtæki fara til að ná árangri verða einnig sífellt fjölbreyttari og margslungnari.

Til að efla möguleika stjórnenda til að stjórna stefnumiðað er mikilvægt að peir séu vel að sér, bæði í formlegum og óformlegum starfsháttum fyrirtækisins. Hér skal sérstaklega bent á að ná utan um a) próunarskeið fyrirtækisins, b) vinnubrögð pess og venjur og c) pað sem skiptir máli til að ná árangri.

Próunarskeið: Öll fyrirtæki eiga sér sögu. Hefð er fyrir pví í greiningarhluta stefnumótunarvinnu að velta pví upp hvar fyrirtæki er á sínum æviferli ${ }^{32}$. Stefnumótunarvinna snýst um að gera reksturinn sem árangursríkastan til framtíðar, en mikilvægur páttur í pví er að fyrir hendi sé skilningur á próun fyrirtækisins og geta til að draga lærdóm af fortíðinni. Starfsemi fyrirtækja yfir tíma markast helst af afdrifaríkum atburðum, t.d. forstjóraskiptum, flutningi í nýtt húsnæði, markaðsávinningum, rekstrarerfiðleikum, samruna eða jafnvel rekstrarstöðvun í einni

32 Sjá Greiner, L. 1972; Jørgensen, K.A., 1985. 
eða annarri mynd. Tímaskeiðin hafa sérkenni og sum pessara sérkenna eru pýðingarmeiri en önnur og sum hafa varanlegri áhrif. Próunarskeið varpa ekki aðeins ljósi á próun í starfsemi fyrirtækisins sem er til skoðunar heldur einnig á menningu pess og brag. Menning fyrirtækis er lýsandi fyrir pað sem er viðvarandi í fyrirtæki og má nánast líkja við sjálfstýringu. Erfitt er að ráða í menningu og mjög erfitt er að breyta fyrirtækismenningu. Til að ráða í menningu má t.d. skoða siði og venjur, sögur, tákn og tungumálið sem notað er í fyrirtækinu.

Vinnubrögð og venjur: Mikilvægt er að draga sérstaklega fram upplýsingar um ráðandi vinnubrögð og venjur í fyrirtækinu. Pessi atriði virðast oft einföld en pýðing peirra er mikil. Vinnubrögð og venjur ráða oft úrslitum um pjónustu- og afhendingargetu fyrirtækja. Færni, kunnátta og geta birtast í starfsháttum og atferli sem fyrirtækinu er tamt. Pekking skapast gegnum samvirkni og samtengingu starfsmanna, viðskiptavina, birgja og fjölmargra annarra. Pekking og kunnátta síast inn í atferlismunstrið, bæði beint og óbeint. Fyrirtæki sýna jafnframt aukna viðleitni til að herða á lærdómsferlinu ${ }^{33}$ og draga fram hið sérstaka við mannauðinn og tengslaauðinn, m.a. gegnum formbindingu í skipulagsauð ${ }^{34}$. Vinnubrögð og verkferlar eru skráðir og samskiptasagan er geymd eftir pví sem kostur er, t.d. á stafrænu formi. Aukin formfesta í varðveislu upplýsinga og pekking á venjum starfsmanna koma pó aldrei í staðinn fyrir pá kunnáttu og færni sem starfsmenn hafa fram að færa í starfi. Hið formlega og óformlega parf að tvinnast saman til að fyrirtæki viðhaldi sköpunarmætti sínum. Petta ber ekki síst að hafa í huga í ljósi pess að vitneskja um pað hvernig fyrirtæki starfar og hvert meginverkefnið er dregur úr pörfinni fyrir að sett séu skilgreind markmið fyrir einstaka pætti starfseminnar. Ef metnaður og umboðsveiting eru fyrir hendi í fyrirtækinu og jákvæð viðspyrna í menningu fyrirtækisins eru góðar aðstæður fyrir sjálfsprottinn árangur.

Árangur: Frumforsenda fyrir markvirkni og skilvirkni í fyrirtæki er að starfsemi sé árangursmiðuð. Árangur er pví lykilhugtak í stjórnun. Árangur mældur með peirri verðmætasköpun sem starfsemin leiðir til. Árangurinn er niðurstaða úr ferli verðmætasköpunar. Margir pættir hafa áhrif á árangur starfseminnar og aðferðir til að mæla árangur eru af ýmsum toga. Sterkust er hefðin fyrir árangursmati með reikningshaldi, fjárhagslegu uppgjöri og kennitöluútreikningi. Hin síðari ár hefur verið lögð áhersla á að víkka út árangursmatið og samhæfa pað ${ }^{35}$. Í samhæfðu árangursmati er horft til verðmætasköpunar í stærra samhengi en áður og með jafnvægi í huga. Vinna er lögð í að finna viðmið og mælikvarða sem segja fyrir um árangur á öllum stigum ferlisins. Verðmætasköpun fer fram með öflun og nýtingu peirra aðfanga/auðlinda sem fyrirtæki hefur úr að spila, framleiðslu afurða/pjónustu og með markaðsstarfi. Kjarni málsins er að nýting auðlinda er forsenda tekjuöflunar og pess vegna er mikilvægt að horfa á allt verðmætasköpunarferlið við mat á árangri. Verðmætasköpuninni má líkja við spíral, p.e. stöðugt endurtekið ferli í tímans rás, par sem árangurinn veltur á ávinningi viðskiptavinarins og annarra hagsmunaaðila. Í pví felst áskorun um að gera starfsemi markvirka. Markvirkni er pað að gera rétta hlutinn, á réttum stað og á réttum tíma. Markvirkni má finna með pví að huga að tvennu. Annars vegar réttmæti, viðurkenningu og ánægju með pað sem gert er og hins vegar

\footnotetext{
33 Starkey, 1996.

${ }^{34}$ Stewart, 1997; Bukowitz \& Williams, 1999.

35 Samhæft árangursmat er pýðing á „,balanced scorecard“, sjá Kaplan og Norton, 1996, 2001.
} 
hagkvæmni við framkvæmdina. Að pessu má huga á hverju stigi verðmætasköpunarferlisins. Skilningur á peim páttum sem mestu skipta fyrir starfsemina, p.e. lykilárangurspáttum, auðveldar árangursmatið.

Раð er óumdeilt að forsendur rekstrar fyrirtækja taka sífellt breytingum. Вæði stjórnendur fyrirtækja og fræðimenn í stjórnun og stefnumótun hamra á pví að breytingar séu pað eina sem hægt sé að ganga að sem vísu ${ }^{36}$. Til að lifa af verða fyrirtæki stöðugt að aðlagast breyttum forsendum og hafa áhrif á breytingarnar. Óvissan í umhverfinu og margbreytileikinn í starfsemi fyrirtækja gerir pað að verkum að erfitt er að sjá hluti fyrir. Vegna pessa eru miklar líkur á að áætlanir eða viðmið sem eiga að gilda langt fram í tímann geti verið varasamur leiðarvísir og jafnvel komið í veg fyrir lærdóm og nauðsynlega aðlögun. Með pví að leggja áherslu á ferlið í próun fyrirtækisins og greiningarvinnu, í samræmi við framangreint, samhliða framkvæmd stefnumiðaðrar stjórnunar er hægt að ýta undir lærdóm og efla hæfni fyrirtækis í pví að vera pað sem ætlast er til á hverjum tíma ${ }^{37}$.

Hingað til hefur til aðeins verið vikið lítillega að pví að fyrirtæki starfi í flóknu umhverfi. Í umfjöllun um tilvistarvíddina hefur athygli lesandans verið beint að umbjóðendum peirra sem starfa í fyrirtækjum, hagsmunaaðilum fyrirtækja, tilvistarrými fyrirtækja og tilvistarheiti. Í umfjöllun um innihaldsvíddina var dregið fram að viðmiðunin hverju sinni er staða fyrirtækisins í rekstrarumhverfinu, t.d. í hvaða atvinnugrein раð starfar, hverjir séu samstarfsaðilar og viðskiptavinir. Lykilatriði ferlisvíddarinnar er samtenging fyrirtækisins, út á við og inn á við, yfir tíma. Af pessu er ljóst að umhyggjan og næmið fyrir samhengi fyrirtækja er grundvallaratriði í stjórnun, ekki síst í stefnumiðaðri stjórnun.

\subsection{Samhengisvíddin}

Samhengisvíddinni er ætlað að hjálpa stjórnendum að greina og skilja pau atriði sem snerta umhverfi og innviði fyrirtækja. Atriði sem lýsa pví hvernig fyrirtæki er samansett, í hvaða samhengi pað starfar og hvað parf til að pað geti starfað. Samhengi er ómissandi hugtak pví pað varpar ljósi á pætti sem gefa starfsemi fyrirtækja merkingu. Sem slíkt er hugtakið fjölvítt. Pví parf t.d. að huga að hinu efnahagslega samhengi, landfræðilega samhengi, pólitíska samhengi, skipulagslega samhengi, hugarfarslega samhengi og menningarlega samhengi. Vitund um og pekking á samhengi fyrirtækja ${ }^{40}$ er mikilvæg í allri próun fyrirtækja og forsenda skynsamlegra ákvarðana ${ }^{38}$.

Gerður er greinarmunur á ytra samhengi og innra samhengi fyrirtækja. Fyrirtæki parf á starfsmönnum að halda og starfsemin veltur á pví að nauðsynlegir fjármunir séu til staðar. Fyrirtækið sem slíkt er sjálfstæður aðili eða lögaðili. Starfsemin

\footnotetext{
${ }^{36}$ Peter Drucker undirstrikar petta mjög í bókum sínum, t.d. 1968, 1999 og nú síðast 2002. Einnig skal bent á umfjöllun um petta í grein eftir Rolf Lundin og Runólf Smára Steinpórsson sem mun birtast í Scandinavian Journal of Management fljótlega.

${ }^{37}$ Hér má minna á umfjöllun Gareth Morgans um flæði og umbreytingu, 1997, bls. 251. 40 Margir fræðimenn undirstrika mikilvægi nokkurs konar kerfisvisku, „,systemic wisdom“, t.d. Bateson, 1972; Weick, 1979; Senge, 1990.

${ }^{38}$ Umfjöllun um áhrif af páttum í samhengi á ákvarðanatöku er að finna hjá James G. March, 1991.
} 
fer ávallt fram í tilteknu umhverfi og par er að finna fleiri aðila, einstaklinga og hópa sem eiga pátt í starfinu. Fyrirtæki er pannig opið kerfi sem parf á margs konar aðföngum að halda úr umhverfinu og tilvist pess veltur á pví að eftirspurn sé eftir afurðum pess $^{39}$.

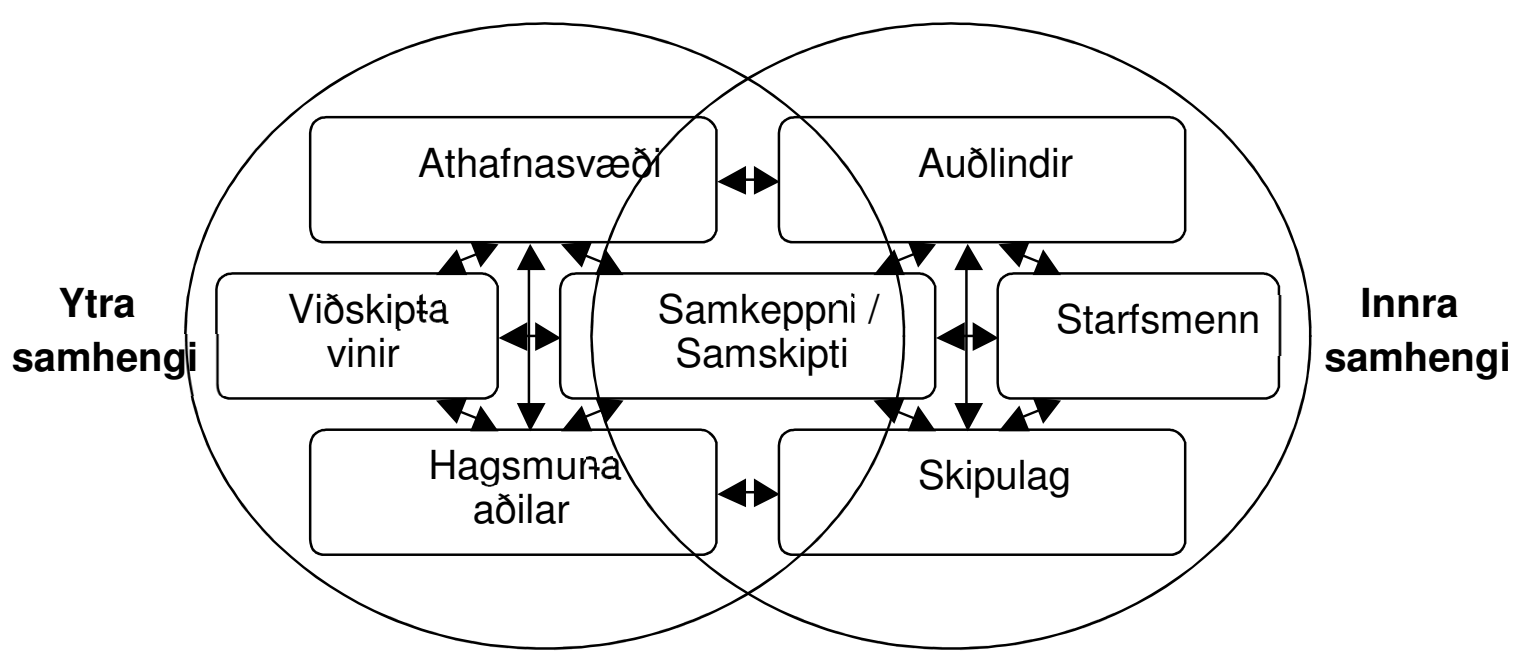

Mynd 5. Stefnumiðað samhengi

Næmni fyrir pví mikilvæga í samhengi fyrirtækja er pví ein af lykilforsendum stefnumiðaðrar stjórnunar. Раð er verkefni stjórnenda að vera vakandi yfir samhengi fyrirtækisins og gera pað stefnumiðað. Mikilvægt er að huga sérstaklega að eftirfarandi atriðum: I) ytra samhengi, og par undir; a) athafnasvæði, b) hagsmunaaðilar, c) viðskiptavinir, d) samkeppni; II) innra samhengi, og par undir; e) samskipti, f) auðlindir, g) starfsmenn, og h) skipulag.

Ytra samhengi: Mjög algengt er að lýsa ytra umhverfi fyrirtækja bæði sem almennu umhverfi og viðskiptaumhverfi. Ytra umhverfið má skipta í mismunandi geira ${ }^{40}$. Pessir geirar gefa hugmynd um tilvistarrými fyrirtækisins, p.e. pað svigrúm sem pað hefur til að stunda sín viðskipti og skapa ávinning fyrir pá sem standa að pví og hafa af pví hag. Gott tilvistarrými er grundvallarforsenda fyrir vöxt og viðgang fyrirtækis og stöðugt parf að fylgjast með pví. Við pá greiningarvinnu parf að taka mið af peirri óvissu sem reksturinn býr við. Óvissan ræðst m.a. af pví hversu margir pættir í umhverfinu skipta máli fyrir rekstrarniðurstöðuna og hvort pessir pættir geti eða séu líklegir til að breytast fyrirvaralaust eða fyrirvaralítið ${ }^{41}$. Eitt mikilvægasta verkefnið í greiningu á ytra umhverfi tiltekins rekstrar er að komast að niðurstöðu um helstu drifkrafta í umhverfinu og pá pætti² sem fyrirtæki verður að ráða við.

Athafnasvæði: Til að gera greiningarvinnuna markvissari er hægt að hafa athafnasvæði fyrirtækisins sem útgangspunkt. Athafnasvæðið er lýsandi fyrir pann markað sem fyrirtækið starfar á og er gjarnan tengt landfræðilegri staðsetningu pess.

\footnotetext{
39 Sjá Richard L. Daft, 2001.

40 Sjá Richard L. Daft 2001, bls. 131.

41 Daft, 2001

42 Hér er vísað til lykilárangurspátta („key factors of success“), sjá K. Ohmae, 1982; Lynch, 2000.
} 
Pegar horft er á markaðinn parf bæði að notast við almenna lýsingu og kastljós. Í hinu almenna ljósi parf einna helst að horfa til hagstjórnarinnar, stjórnmálaumhverfisins, tæknimála, lýðfræðilegra pátta, lagalegs umhverfis og umhverfismála. Kastljósið beinist aftur á móti að einstökum páttum í markaðsumhverfinu sem hafa bein áhrif á pau viðskipti sem fyrirtækið stundar, nánar tiltekið viðskiptaumhverfið. Greining á viðskiptaumhverfinu tengist mjög greiningunni á viðskiptasviðinu, sem hér að ofan var fellt undir innihaldsvídd stefnumiðaðrar stjórnunar. Í viðskiptaumhverfi er m.a. að finna pá aðila sem bjóða aðföng fyrir fyrirtækið og stoðpjónustu hvers konar. Samkeppnisaðilana er par einnig að finna og pá parf að skoða vel ${ }^{43}$. Í greiningarvinnunni er mikilvægt að gera greinarmun á atvinnugreininni sem samkeppnisaðilarnir teljast til og markaðinum sem peir starfa á. Рað fer t.d. eftir pjónustu fyrirtækja hvort pau starfa á fyrirtækjamarkaði eða neytendamarkaði. Markaðurinn samanstendur af viðskiptavinum fyrirtækisins og peim sem mögulega geta orðið viðskiptavinir. Peir aðilar sem hér hafa verið nefndir eru allir meðal hagsmunaaðila fyrirtækja.

Hagsmunaaðilar: Ef starfsemi fyrirtækis snertir hag einhvers pá telst sá hinn sami vera hagsmunaaðili fyrirtækisins. Pessi áhrif á hag viðkomandi geta verið jákvæð eða neikvæð. Af pessum sökum getur verið afar mikilvægt að gera sérstaka greiningu á hagsmunaaðilum fyrirtækisins ${ }^{44}$. Hagsmunaaðilagreining byggist á kenningu um fyrirtækið sem bandalag hagsmunaaðila. Grundvallaratriði er að jafnvægi sé í samskiptum hagsmunaaðila við fyrirtækið. Til að ná utan um greiningu hagsmunaaðila má draga pá sem hafa sambærilega hagsmuni í dilka og kanna hvaða óskir og kröfur peir hafa á fyrirtækið ${ }^{45}$. Skiptingin í hópana getur verið eftirfarandi: eigendur, lánadrottnar, ríkisvaldið, sveitarfélagið, birgjar, starfsmenn og viðskiptavinir. Pekking á vilja og óskum hagsmunaaðila og samskipti við hagsmunaaðila eru afar mikilvæg ef stjórnun á að vera stefnumiðuð, pví að hugmyndirnar og viðmiðin um árangur af starfi fyrirtækisins eru mismunandi eftir pví um hvaða hagsmunaaðila er að ræða.

Viðskiptavinir: Í ytri greiningu skiptir ekki hvað minnstu máli að beina athyglinni að viðskiptavinum fyrirtækisins. Viðskiptavinurinn er sá sem kaupir vöruna eða pjónustuna. Раð er ávinningur viðskiptavinarins sem er ráðandi um ánægju hans og vilja til að eiga frekari viðskipti við fyrirtækið46. Рað er jafnframt mikilvægt að átta sig á pví að notagildi viðskiptavinarins getur ráðist af pví hversu auðvelt honum er gert að sinna sínum viðskiptum og viðskiptavinum ${ }^{47}$. Fyrirtæki sem miðar starfsemina að ávinningi viðskiptavinarins er jafnan nefnt markaðssinnað. Раð gerir sér far um að skilja viðskiptavinina og próar skipulag og starfsemi fyrirtækisins í takt við pann skilning. Páttur í pessu er markhópagreining og markaðshlutun. Áherslan á

\footnotetext{
${ }^{43}$ Stjórnendur hafa fjölmörg próuð greiningartæki sem peir geta gripið til við ytri greiningu. Til að nefna nokkur: PEST-greining, samkeppniskraftagreining, samstarfsgreining,

samkeppnisaðilagreining. Umfjöllun um pessi greiningartæki og önnur er m.a. að finna í bók Richards Lynch 2000.

${ }^{44}$ Sjá t.d. Freeman, 1984; eða Johnsen 1993.

${ }^{45}$ Johnson \& Scholes, 2001.

${ }^{46}$ Petta er undirstrikað af Albrecht, 1992. Bók hans er til í íslenskri pýðingu og úrdráttur í smáriti, 1999. Einnig má benda á Irons, 1994.

${ }^{47}$ Sjá t.d. Normann \& Ramirez, 1994.
} 
viðskiptavininn miðar að pví að tryggja sérstöðu fyrirtækisins og samkeppnisforskot. раð er t.d. gert gegnum markaðsaðgerðir með áherslu á staðfærslu, markaðsboðmiðlun, vörumerki, gæði og viðskiptatryggð. Allar pessar aðgerðir parf að taka til skoðunar í greiningarvinnu.

Samkeppni: Á markaði er mikilvægt að fyrirtæki beini athygli sinni að peim páttum sem stjórnendur geta tekið ákvarðanir um til að bæta samkeppnisstöðuna. Söluráðarnir eru meðal pess sem athygli stjórnenda parf að beinast að. Pekktustu söluráðarnir ${ }^{48}$ eru verðákvarðanir, val á vöru og tilboð um pjónustu, staðarval og kynningarmál. Aðrir söluráðar sem sérstaklega snerta pjónustu eru umgjörð pjónustunnar, starfsmannaval og pátttaka viðskiptavina ${ }^{49}$. Ákvarðanir um söluráða tengjast útfærslu á starfsramma viðkomandi fyrirtækis og snerta sérstaklega samkeppnisstefnu pess. Kjarni málsins er að á markaði er samkeppni um viðskiptavininn. Fyrirtæki verða að huga að keppinautum sínum, gera samanburð og ákveða samkeppnisaðgerðir. Gagnlegt getur verið að skoða samkeppnisstigið, p.e. hvar á ásnum frá fullkominni samkeppni til einkasölu, sú atvinnugrein er sem fyrirtækið starfar innan. Einnig má athuga hvaða skipulagseinkenni eru ráðandi á markaðinum, t.d. í ljósi atriða eins og sampjöppunar, samkeppnishindrana, möguleika á sérstöðu og aðgengis að upplýsingum ${ }^{50}$. Eins er mögulegt að beita samkeppniskraftagreiningu ${ }^{51}$, stefnuhópagreiningu, samkeppnisaðilagreiningu ${ }^{52}$ og greiningu á grundvelli leikjafræði ${ }^{53}$.

Innra samhengi: Рað sem er einkennandi fyrir framsetningu í pessari grein er hversu vítt er litið á samhengi fyrirtækis og hversu mikil skörunin er milli pess sem telst vera ytra og innra samhengi. Mestur vöxtur á vinnumarkaði og í atvinnumálum er í pjónustugreinum par sem verðmætasköpun verður á meðan fyrirtæki og viðskiptavinur eiga samskipti. Tæknipróunin hefur jafnframt leitt til pess að hindranir sem snerta tímamörk, svæðisafmörkun og orkugjafa hafa verið að hverfa ein af annarri. Samhliða hefur hvers konar pekking verið að aukast, nánast í veldisfalli. Í tæknipróun er fólginn drifkraftur breytinga og pekking er eldsneytið sem knýr áfram próunina í efnahagslífinu ${ }^{54}$. Hver framleiðnibyltingin hefur rekið aðra og með hverju nýju tímabili hafa ný úrlausnarefni komið fram. Til að ná utan um möguleikana til verðmætasköpunar í dag er mikilvægt fyrir fyrirtæki og stjórnendur peirra að líta á sig sem hlutaðeigendur í pekkingarsamfélagi og eitt metnaðarfyllsta úrlausnarefnið er að finna leiðir til að auka framleiðni pekkingarstarfsmanna.

Samskipti: Kjarninn í pjónustu- og pekkingarpjóðfélaginu er fólginn í samskiptum. Tæknilega er nú mögulegt að veita sérhverjum viðskiptavini sérhæfða pjónustu á hagkvæman hátt. Pjónusta veltur á samskiptum og samvirkni eins og pegar hefur verið

\footnotetext{
48 Söluráðar er pýðing á „,sales parameter“. Algengt er að vísa til „4 P’s“ pegar fjallað er um hina hefðbundnu söluráða. Pekktasta heimildin um pessi atriði er bók Kotlers sem fyrst var gefin út 1967 og hefur síðan komið í yfir 10 útgáfum.

49 Kotler, 1994

50 Robert M. Grant, 2002.

51 Porter, 1980.

52 Sjá t.d. Grant, 2002.

${ }^{53}$ Dixit \& Nalebuff, 1991.

54 Sjá umfjöllun um áhrif Peters Druckers á stjórnendur í bók Flahertys, 1999.
} 
dregið fram. Ávinningur viðskiptavinarins og viðskiptatryggðin eru í brennidepli. Auðveldara er að sérsníða ávinning að hverjum og einum pví betri samskipti fela í sér greiðari upplýsingamiðlun og meiri pekkingu á pörfum og óskum peirra sem að viðskiptasambandinu koma. Til viðbótar við aukna hagkvæmni samfara nýrri tækni má lækka kostnað vegna pess trausts sem myndast pegar samskipti eru hnökralaus ${ }^{55}$. Dæmi um áherslur á samskipti er t.d. að finna í markaðsfræði par sem mikilvægi „samskipta-markaðssetningar“ 56 er viðurkennt fyrir löngu. Гаð sést best á peirri áherslu sem nú er lögð á CRM-lausnir ${ }^{57}$. Sérhvert fyrirtæki parf pví að vera í góðum tengslum við viðskiptavini sína og aðra hagsmunaaðila. Mestu máli skiptir að huga að pví að samskipti séu sem fyrirhafnarminnst. Lykilatriði er að fyrirtæki horfi á samskiptin frá sjónarhóli viðskiptavinarins, út frá peim ávinningi sem hann hefur af sambandinu, peirri tryggð í orði og verki sem viðskiptavinurinn sýnir og peim verðmætum sem viðskiptasambandið færir fyrirtækinu.

Auðlindir: Рað skiptir miklu að draga fram í dagsljósið pær auðlindir sem nýttar eru í starfsemi fyrirtækis. Auðlindanýtingin ákvarðar framleiðslupættina sem fyrirtækið vinnur úr við framleiðslu vöru og pjónustu ${ }^{58}$. Pegar rýnt er í auðlindir í rekstri er prískiptingin: náttúrulegar auðlindir, mannauður og auðlindir fjármagns ${ }^{59}$ algeng. Auðlindum fyrir tilstilli fjármagns má skipta í tvennt, ápreifanlegan auð og óápreifanlegan. Ápreifanlegi auðurinn er ýmist í formi fastafjármuna eða lausafjármuna. Óápreifanlegi auðurinn er margslungnari. Hann er heldur ekki allur tilkominn vegna fjármagns. Pennan auð má flokka sem viðskiptaauð og skipulagsauð ${ }^{60}$. Oft er vísað til óápreifanlegra verðmæta sem pekkingarverðmæta ${ }^{61}$. Litið er á pekkingu sem sjálfstæða auðlind ${ }^{62}$. Greining á auðlindum hefur pað að markmiði að veita innsýn í pað sem í fyrirtækinu býr. Einkum atriði sem snerta sköpun af öllu tagi, möguleika á samsetningu ólíkra framleiðslupátta og getu til verðmætasköpunar í págu viðskiptavina. Рað er einmitt petta sem er meginatriði í pví sem kalla má auðlindasjónarhornið innan fræða stefnumótunar, p.e. útfærsla á pví sem fyrirtækið býr yfir, kann og getur. Pessi kjarni fræðanna er annar en sá sem sést frá markaðssjónarhorninu, p.e. hvar og fyrir hverja pessi færni nýtist sem best.

Einmitt pess vegna er mikilvægt í greiningu að gera greinarmun á ytra og innra samhengi. Auðlindirnar varpa ljósi á pað innan fyrirtækisins sem liggur til grundvallar sérstöðunni sem pað kann að hafa eða mögulega getur haft á tilteknum markaði. Ýmsar leiðir eru færar í auðlindagreiningu en verða ekki raktar hér63. Mikill áhugi er nú á

\footnotetext{
55 Góð samskipti og gott viðskiptasamband verður oft til pess að lækka viðskiptakostnað, sbr. Douma \& Schreuder, 2002.

56 Relationship Marketing, sbr. Grönroos, 2000.

${ }^{57}$ CRM stendur fyrir Customer Relationship Management.

58 Sjá Penrose, 1959.

59 Sjá m.a. umfjöllun Ágústs Einarssonar, 1994, um framleiðslupættina fjármagn, náttúruauðlindir og vinnuafl. Ágúst dregur einnig fram stjórnunarlega framleiðslupætti.

60 Sjá m.a. Brooking, 1997.

${ }^{61}$ Pekkingarverðmæti er pýðing á „Intellectual Capital“. Brooking flokkar pekkingarverðmæti í "market assets“, "human centred assets", „infrastructure assets" og „intellectual property assets".

62 Sbr. Drucker, 1999.

63 Sjá Lynch, 2000; Grant, 2002;
} 
greiningu á pekkingarverðmætum og ferli pekkingarsköpunar ${ }^{64}$. Mikilvægt er í auðlindagreiningu að slíta hana ekki úr samhengi, heldur sjá auðlindirnar og pað sem pær færa fyrirtækinu í samhengi við pað sem máli skiptir fyrir verðmætasköpun fyrirtækisins og pá möguleika sem pað hefur á að skapa sér sérstöðu.

Starfsfólk: Ein allra mikilvægasta auðlindin sem fyrirtæki hefur úr að spila og sú sem verður sífellt mikilvægari er mannauður. Раð er óhætt að fullyrða að páttur starfsfólks er oft ráđandi um afdrif fyrirtækja. Starfsfólkið vinnur pau verk í fyrirtækinu sem ekki eru unnin með vélum og tækni og ekki er hægt að fela viðskiptavininum að gera. Miklu skiptir að starfsfólk hafi vilja til að vinna vel og hafi ánægju af starfinu. Hluti af pví er að markmið fyrirtækisins og starfsfólksins fari saman. Petta er engan veginn sjálfgefið og рað er margt sem bendir til pess að pörfin fyrir fagmennsku í stjórnun starfsmannamála sé mikil og fari vaxandi. Fyrr var minnst á samskiptafærnina og pjónustuviljann, sbr. umfjöllunina um pjónustu- og pekkingarpjóðfélagið. Pví til viðbótar purfa starfsmenn að búa yfir óvissupoli og miklum aðlögunarhæfileikum. Margt bendir til að starfsöryggi sé að minnka hjá fólki víða um heim. Ástæðuna má m.a. rekja til nýrra lausna í skipulagi fyrirtækja. Samhliða eru vinnustaðir að verða alpjóðlegri, bæði vegna hnattvæðingar og aukins menningarlegs margbreytileika. Til að ná fram pví besta í starfsfólki purfa fyrirtæki að mæta mörgum ögrandi verkefnum í mannauðsstjórnun og pað er mikilvægt að draga fram upplýsingar um pau atriði sem hafa áhrif á hegðun og líðan einstaklinga. Petta eru atriði eins og persónuleg einkenni, starfstengd áhrif, félagsleg staða, samband við yfirmenn, menning fyrirtækisins og fjölskyldumál ${ }^{65}$. Árangur fyrirtækis veltur á pví að starfsmenn gangi í verkin, sýni frumkvæði og leggi sitt af mörkum til að pjónusta verði hnökralaus.

Skipulag: Stefnu fyrirtækis er komið til leiðar fyrir tilstuðlan pess fólks sem kemur að verkunum og раð skipulag sem unnið er eftir. Skipulag gefur til kynna pað fyrirkomulag og pær aðferðir sem notaðar eru til að gera ætlunarverk fyrirtækis að veruleika. Í skipulagi eru dregnar fram línur um hvernig skuli haga verkaskiptingu, sérhæfingu og samræmingu. Sömuleiðis hvaða verk eru í höndum hvers og eins, bæði innan og utan fyrirtækisins. Meðal pess sem fellur undir skipulag fyrirtækja er stjórnskipulag, upplýsingakerfi, framleiðslukerfi, umbunar- og hvatningarkerfi, samskiptakerfi og eftirlitskerfi. Skipulagið er í raun farvegurinn fyrir meðferð auðlinda fyrirtækisins og nýtingu á hráefni, fjármagni og starfskröftum. Skipulagið er umgjörð um ferli ákvarðana, upplýsingavinnslu og boðmiðlunar í fyrirtækinu. Skipulagið er pað tæknilega og félagslega tengslanet sem fyrirtækið hefur til að geta starfað ${ }^{66}$. Við greiningu á skipulagi er mikilvægt að hugsa til pess að flóra skipulagslausna er sífellt að verða fjölbreyttari. Til viðbótar við pekktar skipulagslausnir eru að spretta upp ný form sem gera viðkomandi einingar betur hæfar til að ná tilgangi sínum. Pessi gróska er ekki síst tilkomin vegna tæknipróunar sem gerir mögulegt að sampætta sýndarheiminn og raunheiminn ${ }^{67}$.

Skipulagsgreining parf einnig að taka mið af formlegum og óformlegum páttum í starfseminni, ekki síst peim áhrifum sem menning hefur í fyrirtæki. Stundum er pví

\footnotetext{
${ }^{64}$ Nonaka \& Takeuchi, 1995; Von Krogh et. al. 2000.

${ }^{65}$ Reece \& Brandt, 1996.

${ }^{66}$ Sjá umfjöllun í bókinni Skipulag fyrirtækja eftir Runólf Smára Steinpórsson o.fl. 1995.

${ }^{67}$ Dæmi um petta er m.a. að finna hjá Normann 2001, bls. 63 par sem hann segir frá Shalal Medical Services.
} 
fleygt fram að fyrirtæki sé ekki skipulagsheild heldur menningarheild68. Menning er afar pýðingarmikil í starfsemi fyrirtækja og greining á menningu er órjúfanlegur hluti af mati á pví hvort skipulag í fyrirtæki girðir fyrir eða auðveldar verðmætasköpun. Skipulagið parf ávallt að vera í takti við pað sem fyrirtæki vill vera og vill verða.

Hér lýkur umfjöllun um víddir stefnumiðaðrar stjórnunar. Pessar víddir eru pættir í greiningaraðferð. Peim er ætlað að auðvelda stjórnendum að átta sig á skipulegan hátt á peim fjölmörgu atriðum sem huga parf að í árangursríkri stjórnun fyrirtækis. Í raun og veru eru öll pessi atriði samofin og pað er ekki alltaf augljóst hvaða atriði falla undir hverja vídd. Stundum koma sömu atriði fyrir í fleiri en einni vídd. Рað er eðlilegt. Skilgreiningaratriði er hverju sinni hvar á að draga mörkin. Stefnumiðaða stjórnun verður alltaf að skoða út frá pví fyrirtæki sem unnið er með hverju sinni. Nauðsynlegt er að byggja brú á milli fyrirtækisins og fræðanna í hverju tilviki fyrir sig. Við pá vinnu parf að taka mið af peim raunveruleika sem við er að glíma hverju sinni, innan viðkomandi fyrirtækis og utan.

\section{Lokaorð}

Stefnumiðuð stjórnun fyrirtækis snýst um að tryggja sem árangursríkasta framvindu athafna. Forsenda árangurs er að fyrirtækið sé ávallt vel undirbúið, á réttum stað, á réttum tíma. Раð á við um fyrirtæki eins og einstaklinga, að enginn tryggir eftir á. Раð verður að búa fyrirtæki undir framtíðina og tryggja hæfi pess til tekjuöflunar.

Stefnumiðuð stjórnun snýst um að gera sem mest verðmæti úr peim auðlindum sem eru til ráðstöfunar. Раð má gera með markvissri próun á starfsramma fyrirtækis og tengslum pess við umhverfið. Með starfsramma er dregin fram raunmynd af stöðu fyrirtækis, gegnum lýsingu á tilvistargrundvelli, starfsgrundvelli og skipulagi fyrirtækisins. Раð parf stöðugt að huga að starfsrammanum og vanda til breytinga sem gerðar eru á honum. Mikilvægt er að skoða sögu fyrirtækis og peirrar atvinnugreinar sem pað starfar innan og taka mið af undangenginni próun. Lykilatriði er að fylgjast með pví sem er að gerast og pví sem gera parf núna. Mestu skiptir að spá í framtíðina. Stjórnendur purfa að hafa góðan „leikskilning“. Stefnumiðuð stjórnun snýst um að sjá fyrir og grípa tækifærin sem bjóðast og henta til að ráðstafa auðlindum fyrirtækisins á sem hagkvæmastan og verðmætastan hátt.

Stefnumiðuð stjórnun hefur útgangspunkt í pví sem fyrirtæki býr yfir, pekkir og kann. Ef fyrirtæki er vel staðsett í viðskiptaumhverfinu og hefur áunnið sér traust viðskiptavina á pað góða möguleika. Ef pað er jafnframt vel skipulagt má ætla að pað geti nýtt færni sína og pekkingu til fullnustu. Í umhverfi sem einkennist af óvissu og margbreytni parf fyrirtæki og stjórnendur pess að vera vakandi fyrir öllum víddum og páttum starfseminnar í bæði tíma og rúmi. Рað parf að ganga úr skugga um að allir í fyrirtækinu séu með í stefnumótunarvinnunni og pað parf að byggja stefnuna á peirri innsýn og pekkingu sem er til staðar í fyrirtækinu. En pað má ekki stoppa par. Stefnan og starfsemin verða að fela í sér svigrúm fyrir nýja pekkingu og nýjar áherslur. Grípa

\footnotetext{
${ }^{68}$ Hér er átt við að nær lagi geti verið að sjá fyrirtæki sem „,culture“ frekar en „,structure“, sbr. umfjöllun Per Olof Bergs, 1985.
} 
verður ný tækifæri sem koma upp ef og pegar pau eru í samræmi við grunngildi, meginverkefni og viðskiptaáherslur fyrirtækisins.

Stefnumiðuð stjórnun er síkvikt ferli athafna sem kallar á stöðuga athygli frá stjórnendum. Fyrirtækjum er stjórnað stefnumiðað á degi hverjum, út vikuna, mánuð fyrir mánuð, árum saman. Stefnumiðuð stjórnun er viðvarandi viðfangsefni. Рað er lykilatriði að stjórnendur helgi sig verkefninu og starfsmennirnir sömuleiðis. Allir verða að axla sína ábyrgð á vinnunni og pað er afar mikilvægt að æðstu stjórnendur séu samhentir, gangi á undan með góðu fordæmi og leiði verkið.

Í pessari grein hefur áherslan verið lögð á greiningarpáttinn í stefnumiðaðri stjórnun, par sem lykilatriðið er lýsing og greining á stöðu fyrirtækisins, tækifærum og ógnunum sem og styrkleikum og veikleikum pess. Stundum er pörf á að gera átak í slíkri greiningu og verja til pess hlutfallslega meiri tíma en endranær. Sérstaklega á petta við ef stefnumótunarvinna hefur verið vanrækt í fyrirtæki. Slíka greiningarvinnu parf ávallt að skoða í ljósi athafna og árangurs til lengri tíma. Pví miður er stefnumiðuð stjórnun oft meira í orði en á borði. Par sem pað á við grefur pað undan fyrirtækinu sem í hlut á og getur jafnvel minnkað tiltrú á pær leiðbeiningar sem fræðin veita stjórnendum og starfsmönnum fyrirtækjanna. Kjarni málsins er að stefnumiðuð stjórnun fyrirtækis verður ekki leyst með skammtímaátaki.

Stefnumiðuð stjórnun er viðvarandi viðfangsefni hjá peim fyrirtækjum sem ná árangri. Stjórnendur og aðrir starfsmenn bera ábyrgð á árangri fyrirtækisins og eru í aðalhlutverki í stefnumótunarvinnunni. Lykilatriði er að vinna starfsmanna sé stefnumiðuð á degi hverjum.

\section{Heimildir}

Albrect, K. (1992). The Only Thing That Matter: Bringing the Power of Customer into the Center of your Business. New York: Harper Business.

Albrect, K. (1999). Ávinningur viðskiptavinarins. Reykjavík: Bókaklúbbur Atvinnulífsins. Andrews, K. R. (1987). The Concept of Corporate Strategy. Homewood: Irwin.

Ansoff, I.H. (1965). Corporate Strategy. New York: McGraw Hill.

Ágúst Einarsson (1994). Pættir í rekstrarhagfræði. Reykjavík: Framtíðarsýn.

Bateson, G. (1972). Steps to an Ecology of Mind. New York: Ballantine.

Berg, P.O. (1985). Organization Change as a Symbolic Transformation Process, í P.J. Frost et. al. (eds). Organizational Culture. Beverly Hills: Sage Publications.

Berg, P.O. \& C. Jonsson (1991). Strategisk ledning på politiska marknader:

Opinionsbildning och intern förankring i förvaltninger och folkrörelsesorganisationer. Lund: Studentlitteratur.

Brooking, A. (1997). Corporate Memory: Strategies for Knowledge Management. London: International Thomson Business Press.

Bukowitz, W.R., \& Williams, R.L. (1999). The Knowledge Management Fieldbook. Harlow: Pearson Education Ltd. 
Chaffee, E.E. (1985). Three Models of Strategy. Academy of Management Review, 10(1), 89-96.

Chandler, A.D. jr. (1962). Strategy and Structure, MIT Press.

Daft, R.L. (2001). Organization Theory and Design, Cincinnati, South Western.

De Wit, B. \& Meyer, R. (eds.) (1994). Strategy: Process, Content, Context: An International perspective. Minneapolis, St. Paul: West Publishing.

Dixit, A.K. \& Nalebuff, B.J. (1991). Thinking Strategically: The Competitive Edge in Business, Politics, and Everyday Life. New York: W.W. Norton \& Company.

Drucker, P.F. (1968). The Age of Discontinuity: Guidelines to Our Changing Society. New York: Harper \& Row Publishers.

Drucker, P.F. (1999). Management Challenges of the 21st. Century. New York: Harper Business.

Drucker, P.F. (2002). Managing in the Next Society. New York: T.T. ST. Martin's Press.

Douma, S., \& Schreuder, H. (2002). Economic Approaches to Organizations 3. ed. Harlow: Pearson Education Ltd.

Grant, R.M. (2002). Contemporary Strategy Analysis: Concepts, Techniques, Applications. Oxford: Blackwell Publishers Inc.

Greiner, L.E. (1972). Evolution and Revolution as Organizations Grow, Harvard Business Review 50, July-August.

Grönroos, C. (2000). Service Managment and Marketing: A Customer Relationship Approach 2.ed. Chichester: John Wiley \& Sons Ltd.

Flaherty, J.E., \& Drucker, P.F. (1999). Shaping The Managerial Mind: How the World's Foremost Management Thinker Crafted the Essentials of Business Success. San Francisco: Jossey-Bass Publishers Inc.

Freeman, R.E. (1984). Strategic Management: A Stakeholder Perspective. Massachusetts: Pitman Publishing Inc.

Irons, K. (1994). Managing Service Companies: Strategies for Success. Wokingham: Addison-Wesley Publishing Company.

Jenkins, M., \& Ambrosini, V. (2002). Strategic Management: a multiperspective approach. Basingstoke: Palgrave.

Johnsen, E. (1993). Strategisk analyse og syntese: En kvalitativ metode, København:

Handelshøjskolens Forlag.

Johnson, G., \& Scholes, K. (2002). Exploring Corporate Strategy: Text and Cases 6.ed. Harlow: Pearson Education Ltd.

Judson, A.S. (1996). Making Strategy Happen: Transforming Plans into Reality, 2.ed. Cambridge: Blackwell Publishers Inc.

Jørgensen, K.A. (1977). Strategisk ledelse i mellemstore virksomheder. København: Institut for Erhvervsøkonomi og Ledelse, HHK. 
Kaplan, R.S. \& Norton, D.P. (1996). The Balanced Scorecard: Translating Strategy into Action. Boston: Harvard Business School Press.

Kaplan, R.S. \& Norton, D.P. (2001). The Strategy Focused Organization: How Balanced Scorecard Companies Thrive in New Business Environment. Boston: Harvard Business School Press.

Kotler, P. (1967). Marketing Management: Analysis, Planning, Implementation, and Control. Englewood Cliffs: Prentice Hall.

Kotler, P. (1994). Marketing Management: Analysis, Planning, Implementation, and Control 8ed. Englewood Cliffs: Prentice Hall.

Lynch, R. (2000). Corporate Strategy, 2ed. Harlow: Pearson Education Ltd.

March, J.G. (1991). How Desicisions Happen in Organizations. Human-Computer Interaction, Volume 6, 95-117.

Mintzberg, H. (1987). Crafting Strategy. Harvard Business Review, July-August.

Mintzberg, H. (1994). The Rise and Fall of Strategic Planning. London: Prentice Hall.

Mintzberg, H., Ahlstrand, B. \& Lampel, J. (1998). Strategy Safari. Hemel Hempstead: Prentice Hall.

Morgan, G. (1997). Images of Organizations, 2.ed. Newbury Park: Sage Publications.

Nelson, R.R., \& Winter, S.G. (1982). An Evolutionary Theory of Economic Business, Cambridge, The Belknap Press of Harvard University Press.

Nonaka, I. \& Takeuchi, H. (1995). The Knowledge Creating Company: How Japanese Companies Create the Dynamics of Innovation. New York: Oxford University Press.

Normann, R. (1984). Service Management: Strategy and Leadership in Service Business. Chichester: John Wiley \& Sons Ltd.

Normann, R. \& Ramirez, R. (1994). Designing Interactive Strategy. Chichester: John Wiley \& Sons Ltd.

Normann, R. (2001). Reframing Business: When the Map Changes the Landscape. Chichester: John Wiley \& Sons Ltd.

Ohmae, K. (1982). The Mind of the Strategist. New York: McGraw Hill.

Penrose, E.T. (1959). The Theory of the Growth of the Firm. Oxford: Basil Blackwell.

Pettigrew, A.M. \& Whipp, R. (1991). Managing Change for Competitive Success. Oxford: Blackwell Publishers.

Porter, M. (1980). Competitive Strategy: Techniques for Analysing Industries and Competitors. New York: Free Press.

Porter, M. (1985). Competitive Advantage. Boston: Free Press.

Quinn, J.B. (1980). Strategies for Change: Logical Incrementalism. Englewood Cliffs: Irwin.

Reece, B.L. \& Brandt, R. (1996). Effective Human Relations in Organizations, 6.ed. Boston: Houghton Mifflin Company.

Rolf A. Lundin \& Runólfur Smári Steinpórsson (Forthcoming). Studying organizations as temporary, Scandinavian Journal of Management. 
Runólfur Smári Steinpórsson (1994), Rannsóknir á markvissri stjórnun atvinnupróunarfélaga, Friðrik H. Jónsson ritstj., Ráđstefna um rannsóknir í félagsvísindum. Reykjavík: Félagsvísindastofnun Háskóla Íslands.

Runólfur Smári Steinpórsson (1995), Strategisk ledelse af integrerede mellemsektororganisationer, Handelshøjskolen i København, Ph.D. serie 5.95.

Runólfur Smári Steinpórsson, Marteinn Pór Arnar \& Sigurður Arnar Jónsson (1995) Skipulag fyrirtækja. Reykjavík: Framtíðarsýn hf.

Runólfur Smári Steinpórsson (1999). Markviss stjórnun, Dropinn, 1. tbl.

Runólfur Smári Steinpórsson \& Anders Söderholm (2002). Strategic management as multi-contextual sensemaking in intermediate organizations. Scandinavian Journal of Management, 18, 233-248.

Senge, P. (1990). The Fifth Discipline: The Art \& Practice of The Learning Organization. New York: Doubleday.

Schendel, D.E., \& Hofer, C.W. (eds.) (1979). Strategic Management: A New View of Business Policy and Planning. Boston: Little, Brown and Company.

Stewart, T.A. (1997). Intellectual Capital: The New Wealth of Organizations. London: Nicholas Brealey Publishing Ltd.

Stabell, C.B., \& Fjellstad, Ø.D. (1996). Value Configuring for Competitive Advantage: On Chains, Shops and Networks. Working Paper. Norwegian School of Management - BI.

Starkey, K. (ed.) (1996). How Organizations Learn. London: International Thompson Business Press.

Von Krogh, G., Ichijo, K., \& Nonaka, I. (2000). Enabling Knowledge Creation: How to Unlock the Mystery of Tacit Knowledge and Release the Power of Innovation. New York: Oxford University Press.

Weick, K.E. (1979). The Social Psychology of Organizing. Reading MA. Addison-Wesley.

Weick, K.E. (1995). Sensemaking in Organizations. Thousand Oaks: Sage Publications Inc. Whipp, R., Rosenfeld, R., \& Pettigrew, A. (1988). Understanding Strategic Change Processes: Some Preliminary British Findings, í A.M. Pettigrew (ed.), The Management of Strategic Change. Oxford: Basic Blackwell. 
